\title{
Zdolność absorpcji wiedzy i percepcja roli kapitału ludzkiego w innowacyjnych środowiskach przedsiębiorczości w regionie łódzkim
}

\section{Przedsiębiorstwa oparte na wiedzy jako determinanta konkurencyjności lokalnego środowiska przedsiębiorczości}

Procesy rozwoju lokalnego i regionalnego prowokowane są przez różnorodne czynniki zarówno o charakterze społecznym, gospodarczym, jak i przestrzennym. Niewątpliwie jednak przedsiębiorcy oraz działające $\mathrm{w}$ ich otoczeniu instytucje i organizacje, tworząc zorganizowane i spójne środowiska, są podstawą generowania dynamiki rozwoju. Analiza środowisk przedsiębiorczości stała się warunkiem koniecznym skutecznych badań regionalnych, mających na celu formułowanie wyjaśnień w zakresie procesów rozwoju, zwłaszcza w kontekście wykorzystywania zasobów wiedzy i kapitału ludzkiego ${ }^{1}$. A. Marshall, zwracając uwagę na wagę właściwości środowiska wskazywał także, iż generuje ono atmosferę przemysłową, realnie oddziałującą na zdolności produkcyjne i wzrost gospodarczy, dzięki procesom specjalizacji oraz przede wszystkim niepowtarzalności lokalnego kapitału ludzkiego i społecznego. Wartość środowisk przedsiębiorczości dla podmiotów gospodarczych wynika przede wszystkim z ich użyteczności i praktycznej orientacji istnienia. Specyfika taka skutkuje wysoką skutecznością w zakresie determinowania innowacyjności podmiotów działających w środowisku. P. Aydalot wskazał, iż dobrze zorganizowane środowisko posiada zdolność do generowania innowacji oraz przejmowania postępu technicznego. Środowiska w tym rozumieniu stają się inkubatorami procesów inno-

\footnotetext{
* Adiunkt, Katedra Gospodarki Regionalnej i Środowiska, Wydział Ekonomiczno-Socjologiczny, Uniwersytet Łódzki. E-mail: zbycho@uni.lodz.pl

${ }^{1}$ P. A. Julien, A Theory of local entrepreneurship in the knowledge economy, Edward Elgar Publishing, UK 2007, p. 73.
} 
wacyjnych $^{2}$. D. Maillat, O. Crevoisier i B. Lecoq określają środowisko przedsiębiorczości jako zlokalizowany zbiór, uformowany i zintegrowany w sieci, wyposażony w zasoby materialne (np. infrastruktura, przedsiębiorstwa) i niematerialne (np. umiejętności, wiedza), którymi rozporządzają i zarządzają liczni aktorzy lokalni (firmy, instytucje publiczne i prywatne) ${ }^{3}$. „Środowisko przedsiębiorczości jest więc kategorią przestrzenną, w której bliskość położenia podmiotów względem siebie jest czynnikiem sprawczym jego powstawania", ale nie wystarczającym. To również kategoria kognitywna, społeczna i ekonomiczna ${ }^{4}$. M. Storper dodaje, że jest to zróżnicowany system regionalnych instytucji, norm, praktyk działania, prowadzących do wzrostu innowacyjności podmiotów w nim uczestniczących ${ }^{5}$.

Środowisko posiada własną kulturę, która jest owocem długoletniej historii i tradycji. Jako wypadkowa wiedzy i umiejętności, środowisko jest scharakteryzowane poprzez istnienie zlokalizowanego systemu, powiązanego stosunkami typu współpraca - konkurencja między aktorami ${ }^{6}$. Relacje współpraca - konkurencja $\mathrm{z}$ jednej strony oparte są na logice rynkowej, $\mathrm{z}$ drugiej natomiast na systemie formalnych i nieformalnych norm, wynikających z bliskości położenia, wspólnie podzielanych zwyczajach, tradycjach i konwencjach, których podstawą jest system wzajemnych oczekiwań partnerów działających w tym samym środowisku. Wzajemne rozpoznanie, zaufanie jak również właściwości kapitału ludzkiego zaangażowanego w jego działalność, kształtują podstawy warunków rynkowych funkcjonowania podmiotów gospodarczych. W znacznej mierze od stopnia integracji środowiska i wartości kapitału ludzkiego zależy wysokość kosztów transakcyjnych, generowanych $\mathrm{w}$ procesach rynkowych przez podmioty gospodarcze. Twierdzenie to znajduje swoje uzasadnienie zarówno na gruncie teorii kosztów transakcyjnych ${ }^{7}$, teorii sieci, środowisk innowacyjnych ${ }^{8}$, a także koncepcji bliskości ${ }^{9}$. Coraz częściej

${ }^{2}$ GREMI (Groupe de Recherche Européen sur les Milieux Innovateurs) - Europejski zespół badawczy, prowadzący badania nad innowacyjnymi środowiskami przedsiębiorczości Badaniom na temat terytorialnego umiejscowienia procesu innowacyjnego i środowisk innowacyjnych poświęcono także dużo uwagi w ramach prac z zakresu „Geografii innowacji” (Z. Acs, D. Audretsch, M. P., Feldman).

3 A. Hsaini, Le depassement des eonomies d'agglomeration comme seules sources explicatives de l'efficacite des systemes de production territorializes, Revue d'Economie Regionale et Urbaine 2000, no. 2, s. 224.

${ }^{4}$ A. Ochojski, B. Szczupak, T. Zieliński, Regionalne środowisko przedsiębiorczości. Problematyka badawcza, [w:] Przedsiębiorczość i konkurencyjność a rozwój regionalny, A. Klasik (red.), Prace Naukowe Akademii Ekonomicznej w Katowicach, Katowice 2006, s. 306.

${ }^{5} \mathrm{M}$. Storper, The regional word. The territorial development in global economy, Guilford Press, 1997, s. 17.

${ }^{6}$ A. Hsaini, Le depassement des eonomies d'agglomeration comme seules sources explicatives de l'efficacite des systemes de production territorializes, Revue d'Economie Regionale et Urbaine 2000, no. 2, s. 224.

${ }^{7}$ Ł. Hardt, Ekonomia kosztów transakcyjnych - geneza i kierunki rozwoju, Wydawnictwa Uniwersytetu Warszawskiego, Warszawa 2009.

${ }^{8}$ F. Martinelli, F. Moulaert, O. Ailenei, Territorial innovation models: a critical survey of the international literature, Institut Fédératif de Recherche sur les Économies et les Sociétés Indus- 
produktywność wiedzy staje się czynnikiem rozstrzygającym o miejscu zajmowanym przez dany kraj czy przedsiębiorstwo na rynku globalnym ${ }^{10}$. Wiedza człowieka i zasoby intelektualne są obecnie najbardziej wartościowym aktywem każdej spół$\mathrm{ki}^{11}$. Sytuacja ta zdeterminowała pojawienie się nowej klasy podmiotów gospodarczych - przedsiębiorstw opartych na wiedzy. Przedsiębiorstwa takie posiadają następujące cechy: wytwarzają produkty bogate w wiedzę, czyli takie których ponad $50 \%$ wartości stanowi wiedza lub takie które dostarczają usługi oparte na wykorzystaniu wiedzy w większym stopniu niż na pracy fizycznej; zatrudniają wysokiej klasy specjalistów tzw. pracowników wiedzy, stanowiących trzon wszystkich zatrudnionych; o ich wartości rynkowej w decydującym stopniu przesądza wartość kapitału intelektualnego, a to znaczy, że stosunek wartości rynkowej do wartości księgowej jest większy od 2, czyli można powiedzieć, że to co nie jest ujęte w bilansie jest więcej warte, niż wynosi wartość księgowa ${ }^{12}$. Różnica miedzy wartością księgowa, a wartością rynkową nazywana jest wskaźnikiem q-Tobina ${ }^{13}$. Przedsiębiorstwa oparte na wiedzy, jako najbardziej dostosowane do współczesnych warunków rynkowych, w naturalny sposób stają się liderami rynków, dystansując konkurencję i jednocześnie wyznaczając przyszłe trendy rozwoju ${ }^{14}$. Przyjmując za definicją Komisji Europejskiej, że konkurencyjność regionów to „zdolność przedsiębiorstw, przemysłu, a także ponadnarodowych ugrupowań, zlokalizowanych w regionie, wystawionych na międzynarodową konkurencję, do osiagania trwałego i relatywnie wysokiego poziomu dochodu i zatrudnienia" można oczekiwać, iż w tym przypadku nie tylko jakość, ale także ilość tego typu przedsiębiorstw stanowić będzie o potencjale rozwojowym regionu ${ }^{15}$.

trielles, Intermediate report 2002, s. 7-8; F. Moulaert, F. Sekia, Territorial Innovation Models: A Critical Survey, Debates and Surveys, Regional Studies, 2003, Vol. 37.3.

${ }^{9}$ R. Boschma, R. L. Martin, The Handbook of Evolutionary Economic Geography, Edward Elgar Publishing, UK 2010, s. 122-124.

${ }^{10}$ P. Drucker, Spoleczeństwo pokapitalistyczne, Wydawnictwo Naukowe PWN, Warszawa 1999, s. 152.

${ }^{11}$ E. Skrzypek, Miejsce zasobów niematerialnych $w$ ksztaltowaniu wartości przedsiębiorstwa [w:] Wpływ zasobów niematerialnych na wartość firmy, Wydawnictwo UMCS, Lublin 2003.

${ }^{12}$ E. Skrzypek, Kreatywność pracowników wiedzy i ich wplyw na innowacyjność przedsiębiorstw, materiały konferencyjne z V Konferencji Naukowej z serii „Wiedza i innowacje” pt. „Ochrona wiedzy i innowacji”, Uniwersytet Jagielloński, Kraków, 19-20 stycznia 2009 r.

${ }^{13}$ J. Ryfkin, Wiek dostępu. Nowa kultura hiperkapitalizmu w której płaci się za każda chwile zycia, Wydawnictwo Dolnośląskie, Wrocław 2003, s. 58; T. Stewart, The coins in the Knowledge Bank, „Fortune”, [za:] L. Edvinsson, M.S. Malone, Kapitat intelektualny, Wydawnictwo Naukowe PWN, Warszawa 2001, s. 17.

${ }^{14}$ Dzieje się tak zarówno dlatego, iż traktowane są przez konkurencję jako wzory do naśladowania (best practis), jak i dlatego, iż podmioty te stają się partnerami dla władz publicznych w prowadzeniu polityki rozwoju zarówno jako beneficjenci pomocy publicznej, jak i liderzy projektów innowacyjnych.

${ }^{15}$ I. Pietrzyk, Konkurencyjność regionów w ujęciu Komisji Europejskiej [w:] Polityka regionalna i jej rola w podnoszeniu konkurencyjności regionów, M. Klamut i L. Cybulski (red.), Wrocław 2000, s. 20. 
Przedsiębiorstwa oparte na wiedzy mają większą skłonność i zdolność do integracji lokalnych środowisk przedsiębiorczości, ponieważ ze względu na wysoki poziom specjalizacji potrzebują partnerów outsourcingowych oraz kooperantów (zarówno spośród innych przedsiębiorstw, jak i instytucji $B+R$, instytucji trzeciego sektora czy władz publicznych). Upatrują w zorganizowanym (współpracującym) środowisku efektów skali korzyści, ograniczenia kosztów transakcyjnych oraz socjalizacji ryzyka prowadzenia działalności. Ponadto potrzebują wiedzy sektorów pokrewnych w celu kreowania własnych innowacji. Podmioty o takiej charakterystyce skutecznie wpływają także na poziom innowacyjności całego środowiska przedsiębiorczości, dzięki zjawiskom dyfuzji innowacji, determinowaniu powstawania innowacji $\mathrm{w}$ środowisku oraz procesom rozprzestrzeniania się wiedzy cichej ${ }^{16}$.

Z drugiej strony pamiętać należy, że to lokalne środowisko (otoczenie przedsiębiorstwa opartego na wiedzy) motywuje do działania i determinuje efektywność zarządzania zasobami wiedzy w przedsiębiorstwie ${ }^{17}$. Na tym między innymi polega fenomen funkcjonowania środowisk przedsiębiorczości zdolnych do wygenerowania klastrów.

${ }^{16}$ Pierwotnym źródłem wiedzy jest człowiek, który tworzy ją w wyniku interakcji między wiedza utajona (cicha, milczqca)( M. Polanyi, Tacit Knowing: Its Bearing on Some Problems of Philosophy, Reviews of Modern Physics, 34 (4), Oct. 1962, 601-616) i wiedza artykułowana (dostępna). Wiedza utajona (ang. tacit knowledge) pozostaje zapisana, uwieczniona w pamięci terytorium, jest nieskodyfikowana i nie podlega mechanizmom rynkowym w odróżnieniu do informacji kodyfikowanych podlegających rynkowi i mających cenę. Termin ten wprowadził M. Polanyi wskazując, że ,wiemy zawsze więcej, niż byśmy byli w stanie wyrazić”. Wiedza ukryta to wiedza utrwalona w podświadomości, trudna bądź niemożliwa do skodyfikowania, przekazywana w procesie socjalizacji wiedzy; M. Kolarz, Znaczenie wiedzy i kapitatu intelektualnego we wspótczesnej gospodarce $i$ organizacji [w:] Kapitat ludzki $w$ dobie integracji i globalizacji, B. Kożusznik (red.), Wydawnictwo Uniwersytetu Śląskiego, Katowice 2005, s. 80. Wiedza ta ,jest nierozłącznie związana z ludźmi i jest rezultatem ich talentu, zdolności oraz doświadczeń"; M. Markowska, Zróżnicowanie europejskiej przestrzeni regionalnej w świetle koncepcji gospodarki opartej na wiedzy [w:] Gospodarka lokalna i regionalna w teorii i praktyce, D. Strahl (red.), Prace Naukowe Akademii Ekonomicznej im. O. Langego we Wrocławiu, nr 1161, Wydawnictwo Akademii Ekonomicznej im. O. Langego we Wrocławiu, Wrocław 2007, s. 36. Wykorzystywana jest w życiu codziennym, jednak trudno ją przekazać innym ludziom, gdyż trudno wyjaśnić istotę jej istnienia, jest to więc bardzo często wiedza fachowa, specjalistyczna, którą posiadają tylko niektórzy pracownicy i która stanowi zdecydowanie ważniejsze źródło przewagi konkurencyjnej od wiedzy jawnej; R. Przybyszewski, Kapitat ludzki w procesie kształtowania gospodarki opartej na wiedzy, Wydawnictwo Difin, Warszawa 2007, s. 30-31.

${ }^{17}$ A. Jewtuchowicz, Terytorium $i$ wspótczesne dylematy jego rozwoju, Wydawnictwo Uniwersytetu Łódzkiego, Łódź 2013, s. 139-156; A. Nowakowska, Regionalny wymiar procesów innowacji, Wydawnictwo Uniwersytetu Łódzkiego, Łódź 2011; Z. Przygodzki, Innowacyjne środowiska przedsiębiorczości w kontekście procesów organizacji i regulacji w regionie [w:] Zrozumieć terytorium. Idea i praktyka, A. Nowakowska (red.), Wydawnictwo Uniwersytetu Łódzkiego, Łódź 2013, s. 105-128. 


\section{Cel i metodyka badań innowacyjnych środowisk przedsiębiorczości w regionie łódzkim}

Celem badań jest identyfikacja zdolności do absorpcji wiedzy oraz określenie rangi kapitału ludzkiego wśród czynników, determinujących konkurencyjność innowacyjnych środowisk przedsiębiorczości regionu łódzkiego. Podstawową tezą kalibrującą badania jest stwierdzenie, iż inwestycje w wiedzę i kapitał ludzki w przedsiębiorstwach pozwalają generować przewagi konkurencyjne, dzięki zwiększonej skłonności do innowacyjności przedsiębiorstw. Przystępując do realizacji zadania określono trzy hipotezy badawcze:

1. Przedsiębiorstwa oparte na wiedzy mają świadomość znaczenia wiedzy i kapitału ludzkiego w budowaniu przewag konkurencyjnych dlatego prowadzą w tym zakresie świadomą politykę inwestycyjną. (H1)

2. Pozyskiwanie wiedzy specjalistycznej i kapitału ludzkiego $\mathrm{z}$ otoczenia jest efektywniejsze i korzystniejsze dla przedsiębiorstw niż inwestowanie w wiedzę ze środków własnych, ponieważ równie skutecznie umożliwia osiaganie przewag konkurencyjnych przedsiębiorstwu (H2).

3. Przedsiębiorstwa oparte na wiedzy wykazują wysoką skłonność i zdolność do integracji środowiska przedsiębiorczości, ponieważ potrzebują wiedzy sektorów pokrewnych i właściwego otoczenia instytucjonalnego, w celu kreowania własnych innowacji (H3).

Dokonując operacjonalizacji tak ukierunkowanego obszaru badań, zaplanowano aby wnioskowanie, obok właściwości poznawczych, mogło mieć również charakter aplikacyjny. W konsekwencji badania zrealizowano w przedsiębiorstwach, mających swoją siedzibę w regionie łódzkim. Kryterium podstawowym doboru respondentów było badanie małych i średnich ,przedsiębiorstw opartych na wiedzy". Jednak z uwagi na brak możliwości zastosowania w stosunku do całej populacji małych i średnich przedsiębiorstw $\mathrm{w}$ regionie wskaźnika Q-Tobina, który w sposób obiektywny, za pomocą kryteriów rynkowych, wskazuje podmioty gospodarcze ,oparte na wiedzy”, zastosowano dwie metody alternatywnego doboru respondentów: dobór oparty na kryteriach przyjętych arbitralnie (ex ante) oraz ocenę własną przedsiębiorcy (ex post).

Dobór arbitralny miał charakter złożony i został zrealizowany przy założeniu, że w okresie gospodarki opartej na wiedzy, rywalizację konkurencyjną na rynku wygrywają podmioty wykorzystujące najważniejsze atrybuty tych warunków gospodarowania - innowacje, wiedzę i kapitał ludzki. Stąd populację generalną złożoną z małych i średnich przedsiębiorstw utworzono kwalifikując do badania zwycięzców, laureatów i wyróżnionych we wszystkich konkursach poddających ocenie konkurencyjność i innowacyjność podmiotów gospodarczych, jakie miały miejsce od 1991 do 2011 roku w regionie łódzkim. W ten sposób zidentyfikowano 56 respondentów. Po drugie, posiłkując się wiedzą o wysokim 
poziomie konkurencyjności przedsiębiorstw prowadzących działalność gospodarczą na terenie Łódzkiej Specjalnej Strefy Ekonomicznej i praktycznie nie występowaniu efektu przenoszenia działalności (co nie poddaje w wątpliwość determinacji do inwestowania $\mathrm{w}$ nowoczesny majątek trwały przedsiębiorców lokalizujących się w strefie), do badania zakwalifikowano wszystkie małe i średnie przedsiębiorstwa działające w LSSE - 56 podmiotów (zgodnie ze stanem z dnia 01.12.2011).

Celowo określono kryteria wyboru populacji generalnej oraz uzupełniającej, zakładając, że taki dobór respondentów pozwoli zaangażować w badania przedsiębiorstwa małe i średnie, które charakteryzować się będę potencjalnie najlepszą sytuacją i aktywnością w zakresie zarządzania wiedzą i kapitałem ludzkim $\mathrm{w}$ regionie. Tym samym, celem badań nie jest identyfikacja przeciętnej sytuacji dla statystycznego przedsiębiorcy w regionie w zakresie tematu, a analiza stanu dotychczasowego wykorzystania i zaangażowania aktualnie najważniejszych czynników wzmacniania przewag konkurencyjnych, związanych z inwestycjami w kapitał ludzki i wiedzę. Poznając w ten sposób poziom percepcji, zaangażowania się i zrozumienia roli czynników niematerialnych (w szczególności inwestycji w kapitał ludzki) wśród najlepszych jednostek, można określić najważniejsze potrzeby i wyzwania dotyczące podmiotów regionalnego i lokalnego środowiska przedsiębiorczości wspierających potencjał konkurencyjny przedsiębiorstw. W szczególności, przyjmując założenie realizacji przez nie polityki zorientowanej na wzmacnianie biegunów wzrostu, w tak zdefiniowanej populacji badani pozwolili stosunkowo precyzyjnie zdiagnozować aktualny obraz i niezbędne działania, w gronie regionalnych liderów rozwoju gospodarczego. Jest to ważne z uwagi na możliwość skutecznego kreowania korzystnych warunków dla budowania przewag konkurencyjnych $\mathrm{w}$ okresie przyszłym, pamiętając $\mathrm{w}$ szczególności o sieciowych uwarunkowania rozwoju - łatwości i skłonności do naśladownictwa, potrzebach partnerstwa i kompatybilności, czy wykorzystywaniu best practis jako sposobu poprawy pozycji konkurencyjnej.

$\mathrm{W}$ konsekwencji badanie przeprowadzono $\mathrm{w}$ grupie małych $\mathrm{i}$ średnich przedsiębiorstw ${ }^{18}$, wśród liderów rynku lub podmiotów będących w bardzo dobrej kondycji gospodarczej - charakteryzujących się wysokim poziomem konkurencyjności. W ten sposób wybrano populację generalną 112 przedsiębiorstw. Dla wysokiej skuteczności wnioskowania na poziomie regionu przyjęto, że badania będzie miało charakter zupełny. Jako kryterium uzupełniające liczebność populacji poddanej badaniu, w przypadku odmowy udziału, przyjęto wysoki stopień innowacyjności określony arbitralnie poprzez zaliczenie do pierwszej (225 przedsiębiorstw) lub przynajmniej drugiej grupy (1022 przedsiębiorstwa)

${ }^{18}$ Kierując się w tym względzie jedynie jednym kryterium ustawowym dotyczącym liczby zatrudnionych - do 250 pracowników. Ustawa z dnia 2 lipca 2004 r. o swobodzie działalności gospodarczej Dz.U. 2004 Nr 173, poz. 1807. 
działalności charakteryzujących się wysokim poziomem nasycenia produktów w B+R, za pomocą Klasyfikacji OECD ${ }^{19}$. W ten sposób przygotowano dodatkowy zbiór podmiotów liczący 222 przedsiębiorstwa, z którego metodą losowania prostego uzupełniono liczebność badanej populacji generalnej. Badanie zostało zrealizowane za pomocą kwestionariusza wywiadu metodą CATI w okresie 11.2011-02.2012.

Identyfikując wielkość respondentów, wśród badanych przedsiębiorstw 57\% (64 podmioty) stanowiły mikro przedsiębiorstwa zatrudniające mniej niż 10 osób (w tym 52\% przedsiębiorstwa jednoosobowe), 23\% (26 podmiotów) małe i $20 \%$ (22 podmioty) średnie przedsiębiorstwa. W zdecydowanej większości badani przedsiębiorcy należą do grupy wysoko wykształconych w tym 3 miało tytuł doktora.

Rysunek 1. Wykształcenie przedsiębiorcy

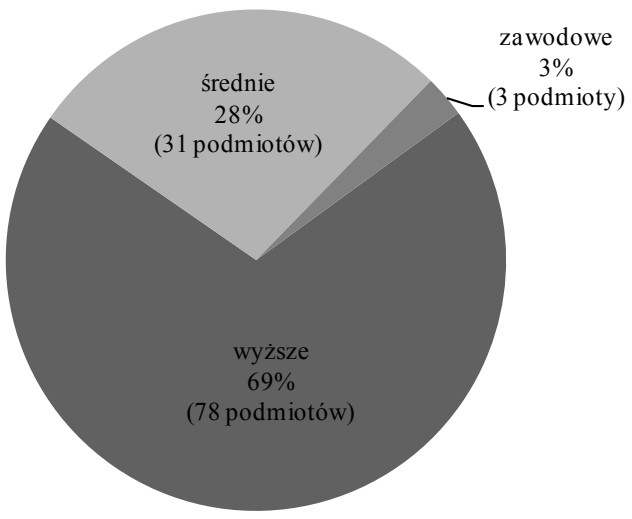

Źródło: opracowanie własne.

Ponad 65\% badanych stanowili respondenci należący do branży usługowej (jednocześnie w grupie tej 5 podmiotów przyznało, że zajmuje się także produkcją i kolejne 5, że istotną ich aktywnością jest działalność handlowa). 33\% to przedsiębiorcy dla których wiodącą aktywnością w realizacji działalności gospodarczej jest produkcja (w tym 9 prowadzi jednocześnie działalność handlowa), niespełna $2 \%$ to respondenci zajmujący się wyłącznie handlem.

${ }^{19}$ Classification of high-technology products and industries, dokument DSTI/EAS/IND/STP (95)I, OECD, Paryż, październik 1995 (Aneks I). 
48 Zdolność absorpcji wiedzy i percepcja roli kapitału ludzkiego...

Rysunek 2. Dominujące rodzaje prowadzenia działalności gospodarczej

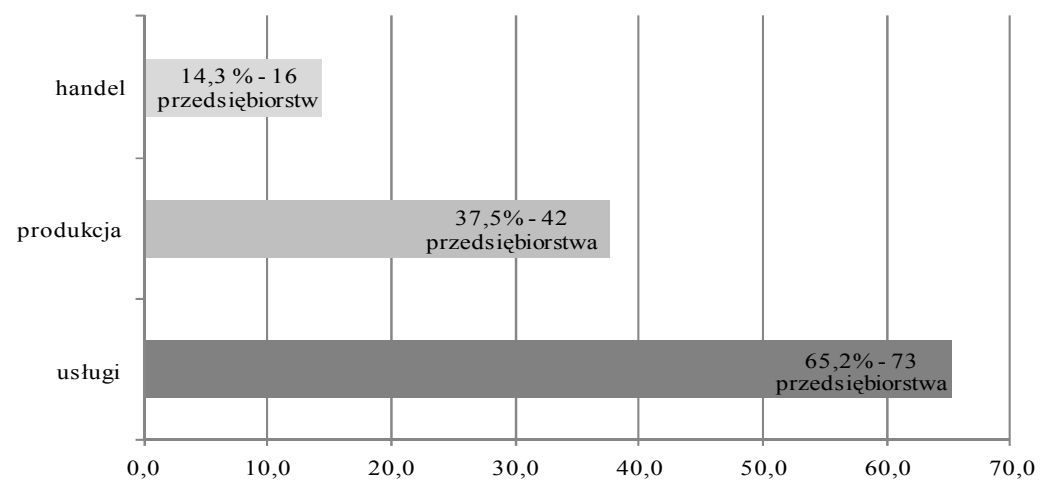

Źródło: opracowanie własne.

Rysunek 3. Liczba badanych przedsiębiorstw według dominujących branż prowadzenia działalności

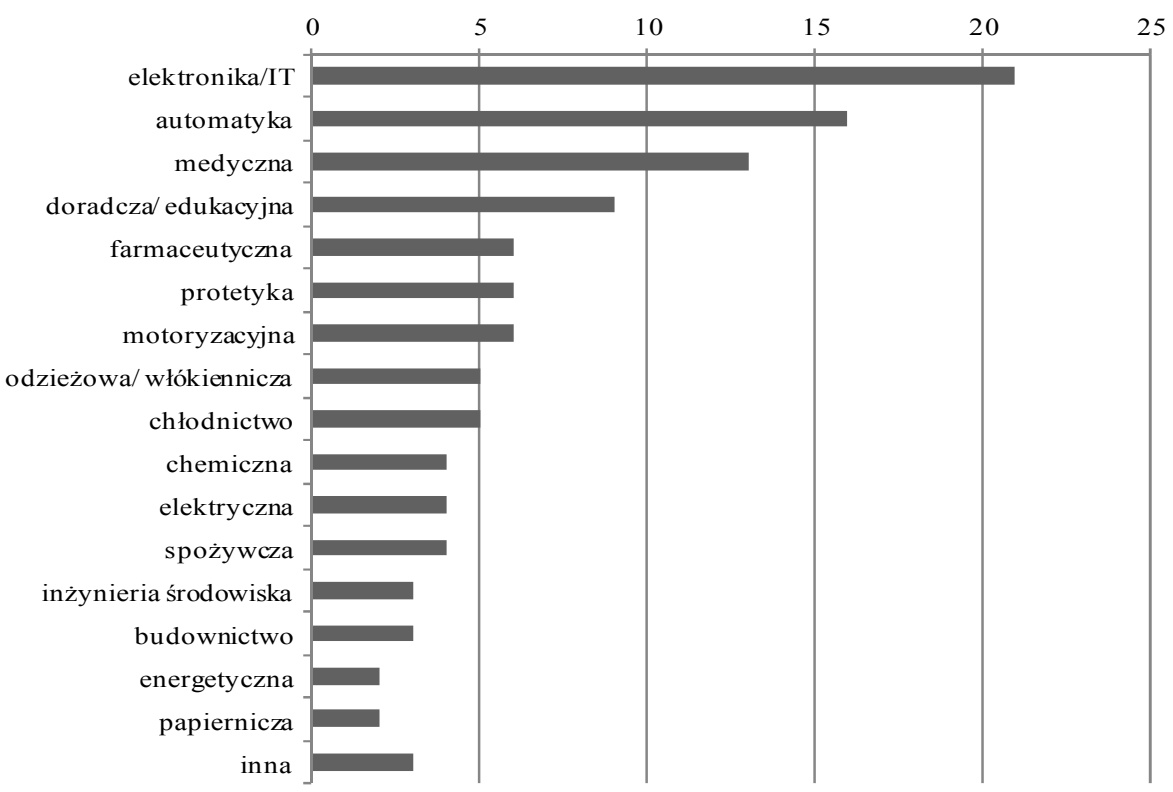

Źródło: opracowanie własne.

Najwięcej badanych przedsiębiorstw reprezentuje branże elektroniczną i IT. W dalszej kolejności są to przedsiębiorstwa branż: automatycznej, medycznej i szkoleniowo-doradczej. W większości branże reprezentowane przez respon- 
dentów zazwyczaj kwalifikowane są do wysoko innowacyjnych ${ }^{20}$. Wyjątkiem w tym katalogu są branże: odzieżowa, spożywcza, budowlana i papiernicza. Jednak w tym przypadku arbitralna kwalifikacja branż nie jest zbieżna z rzeczywistym poziomem innowacyjności przedsiębiorstw zakwalifikowanych do badania.

\section{Percepcja wiedzy jako czynnika konkurencyjności małych i średnich przedsiębiorstw regionu łódzkiego}

Wiedza jest istotnym czynnikiem rozwoju przedsiębiorstw - tak zgodnie stwierdzili niemal wszyscy respondenci uczestniczący w badaniu. Wśród nich jedynie dwa podmioty przyznały, że w ostatnich dwóch latach nie inwestowały w ogóle we wzrost wartości wiedzy w swoim przedsiębiorstwie. 70\% respondentów deklaruje wysoki udział wiedzy i wartości niematerialnych w tworzeniu rynkowej wartości ich przedsiębiorstw. Jedynie 30\% określiło, że podstawą wartości firmy jest nadal majątek trwały. Przy czym większość podmiotów, które udzieliły takiej odpowiedzi to przedsiębiorstwa sektora usługowego, jedynie $4,5 \%$ tej grupy stanowią przedsiębiorcy zajmujących się głównie działalnością produkcyjną. Można zatem wnioskować, iż konkurencyjność działalności produkcyjnej jest bezwzględnie zdeterminowana poziomem zaangażowania wiedzy w działalności gospodarczej. Wniosek ten znajduje również uzasadnienie w dalszej części analizy.

Przedsiębiorstwa oparte na wiedzy poszukują wiedzy o zróżnicowanym charakterze i w różnorodny sposób. Zarówno wysoko cenią dostęp do wiedzy rynkowej, jak i do wiedzy cichej. Wykorzystują dostęp do źródeł wiedzy artykułowanej (m.in.: raporty branżowe, informatory, prasa, książki), jak również dbają o relacje i aktywne uczestnictwo w środowisku przedsiębiorczości, wykorzystując do tego celu kontakty osobiste (m.in.: spotkania nieformalne, targi, konsultacje, ekspertyzy) oraz, choć w mniejszym zakresie, dostępne narzędzia informacyjno-komunikacyjne (m.in.: fora dyskusyjne, platformy tematyczne). W okresie ostatnich dziesięciu lat obraz ten uległ znaczniej zmianie. Szczególnie sytuacja dotycząca zaangażowania i skłonności do inwestycji w wiedzę, jest obecnie znacznie bardziej korzystna od tej, jaka obserwowana była w przedsiębiorstwach produkcyjnych, działających $\mathrm{w}$ regionie łódzkim w latach $2001-2002^{21}$. W tym czasie niespełna $40 \%$ przedsiębiorstw podejmowało współpracę z otaczającym

${ }^{20}$ Classification of high-technology products and industries, dokument DSTI/EAS/IND/STP (95)I, OECD, Paryż, październik 1995 (Aneks I).

${ }^{21}$ Zaznaczyć należy jednak, że wyniki tych badań można porównywać w ograniczonym zakresie, ponieważ nieco inna była wówczas metodyka doboru populacji generalnej (badano przedsiębiorstwa produkcyjne ze zdefiniowanym choć zróżnicowanym poziomem innowacyjności). Ze względu na charakterystykę innowacyjności podmiotów, które wówczas zostały poddane badaniu, 8\% stanowiły podmioty należące do kategorii wysoka i średniowysoka technika (wg klasyfikacji OECD). 
Rysunek 4. Identyfikacja kluczowych czynników rozwoju badanych przedsiębiorstw
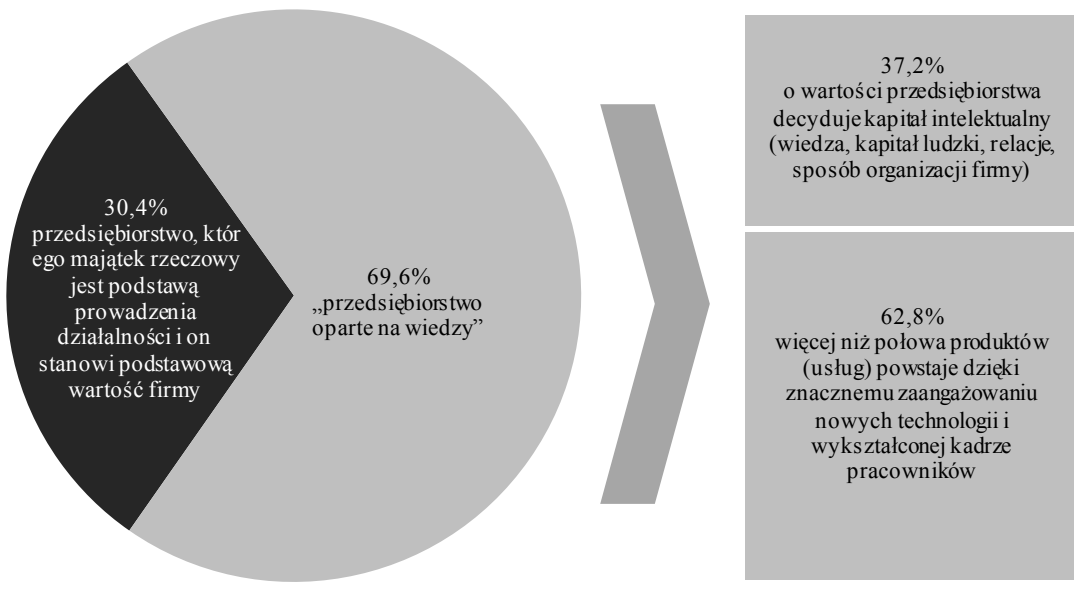

Źródło: opracowanie własne.

środowiskiem przedsiębiorczości, a najczęstszą formą kontaktów z otoczeniem były spotkania osobiste ( $81 \%$ wskazań), targi i wystawy (53\%) oraz Internet $(20 \%)$. Pozostałe formy wymiany wiedzy i informacji miały marginalne znaczenie. Obecnie znacznie wzrósł poziom zapotrzebowania na wymianę wiedzy i informacji w środowisku, praktycznie w każdym dostępnym kanale dostępu do wiedzy. Istotne zmiany dostrzegalne są nawet $\mathrm{w}$ aktywności na rynku własności przemysłowej (patentów i licencji) oraz gotowych do zastosowania rozwiązań technologicznych. W 2001 roku jedynie ok. 8\% badanych wykorzystywało ten kanał dostępu do wiedzy, natomiast obecnie ok. 43\% respondentów deklaruje takie działania. Zmiany te występują także w odniesieniu do zwiększonych skłonności przedsiębiorstw produkcyjnych do zamawiania specjalistycznych konsultacji, ekspertyz i doradztwa. Uogólniając w 2001 roku niespełna 10\% badanych miało kontakt $\mathrm{z}$ sektorem $\mathrm{B}+\mathrm{R}$ lub sektorem pozarządowym, obecnie ok. $57 \%$ badanych deklaruje wykorzystywanie tego typu usług.

Do najważniejszych czynników, motywujących przedsiębiorców do inwestowania we wzrost zasobów wiedzy i rozwój kapitału ludzkiego, zaliczyć należy wymagania klientów, w drugiej kolejności zachowania konkurentów oraz wymagania partnerów biznesowych. Można zatem uznać, iż są to determinanty najbardziej pożądane, wywołujące efekty samonapędzającego się procesu, szczególnie w okresie wzrostu gospodarczego, przy dodatniej dynamice wzrostu konsumpcji i produkcji. Wart odnotowania jest również fakt, że przedsiębiorców motywują w tym zakresie działania władz publicznych (niespełna $44 \%$ odpowiedzi). 
Rysunek 5. Sposób inwestowania we wzrost wartości wiedzy w przedsiębiorstwie

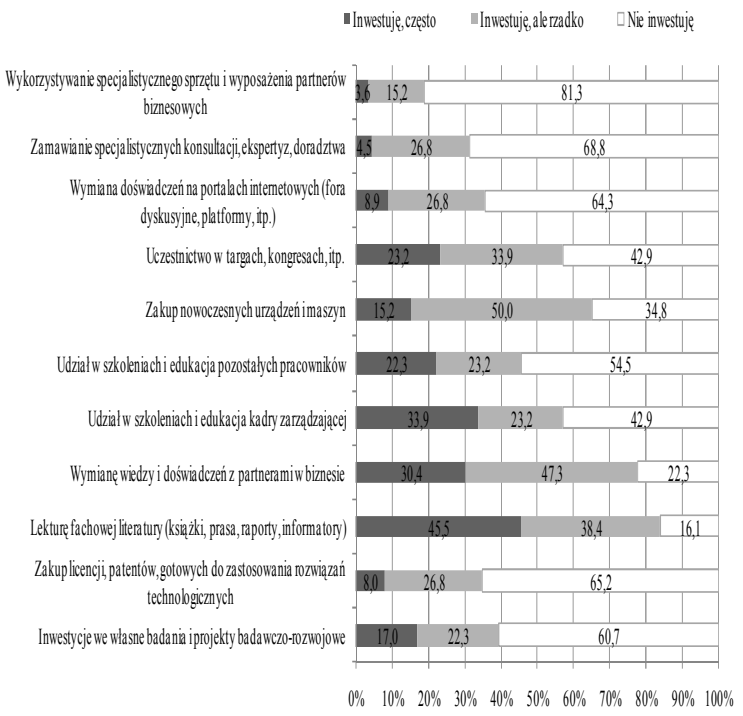

Cała populacja badanych przedsiębiorstw $\mathrm{n}=112$

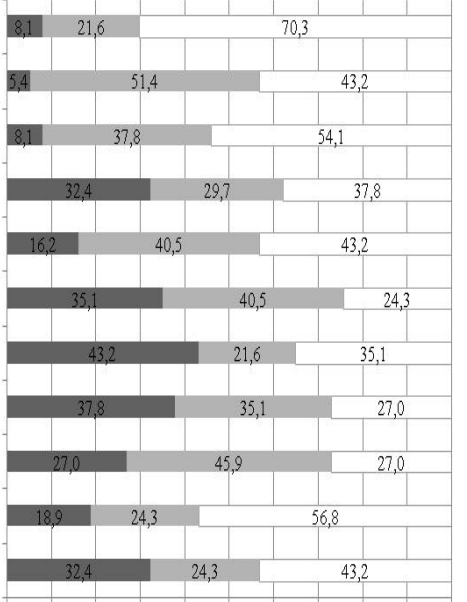

$\begin{array}{lllllllllll}3 \% & 10 \% & 20 \% & 30 \% & 40 \% & 50 \% & 60 \% & 70 \% & 80 \% & 90 \% & 100 \%\end{array}$

Wyniki dla przedsiębiorstw, w których dominuje działalność produkcyjna $\mathrm{n}=37$

Źródło: opracowanie własne.

Odpowiednio ukierunkowana, dopasowana do specyfiki środowiska polityka władz publicznych, może więc być istotną siłą sprawczą rozwoju gospodarczego. Jest to potwierdzenie trafności, przy wyborze sposobu realizacji polityki rozwoju, w oparciu o koncepcję inteligentnych specjalizacji regionalnych. Należy przy tym pamiętać, że największe wyzwania w tym zakresie stoją przed władzami samorządowymi zarówno szczebla regionalnego, jak i lokalnego. Znajduje to swoje uzasadnienie zarówno na gruncie teorii rozwoju lokalnego, jak i teorii bliskości ${ }^{22}$. Istotność zachowań władz publicznych podkreśla także uwzględnianie przez respondentów, jako determinanty inwestowania w kapitał ludzki, roli instytucji szkoleniowo-doradczych oraz edukacyjnych. Ich aktywność zwłaszcza w obecnym okresie, determinowana jest wsparciem finansowym z EFS. Ponadto działania władz publicznych wywołują efekt mnożnikowy, w zakresie dwóch najważniejszych czynników motywujących przedsiębiorców do inwestowania. Są dodatnio skorelowane z czynnikami: zachowania konkurentów i wymagania partnerów biznesowych. Trudno jednak na tym poziomie analizy wnioskować o sile tego efektu ${ }^{23}$.

${ }^{22}$ R. A. Boschma, Proximity and Innovation: A Critical Assessment, Regional Studies, Vol. 39.1, p. 61-74, February 2005.

${ }^{23}$ Problem ten jest przedmiotem badań w ramach projektu badawczego Narodowego Centrum Nauki, pt: Ocena skuteczności regionalnych systemów dystrybucji funduszy strukturalnych Unii 
Rysunek 6. Determinanty inwestowania w wiedzę i kapitał ludzki w przedsiębiorstwach opartych na wiedzy

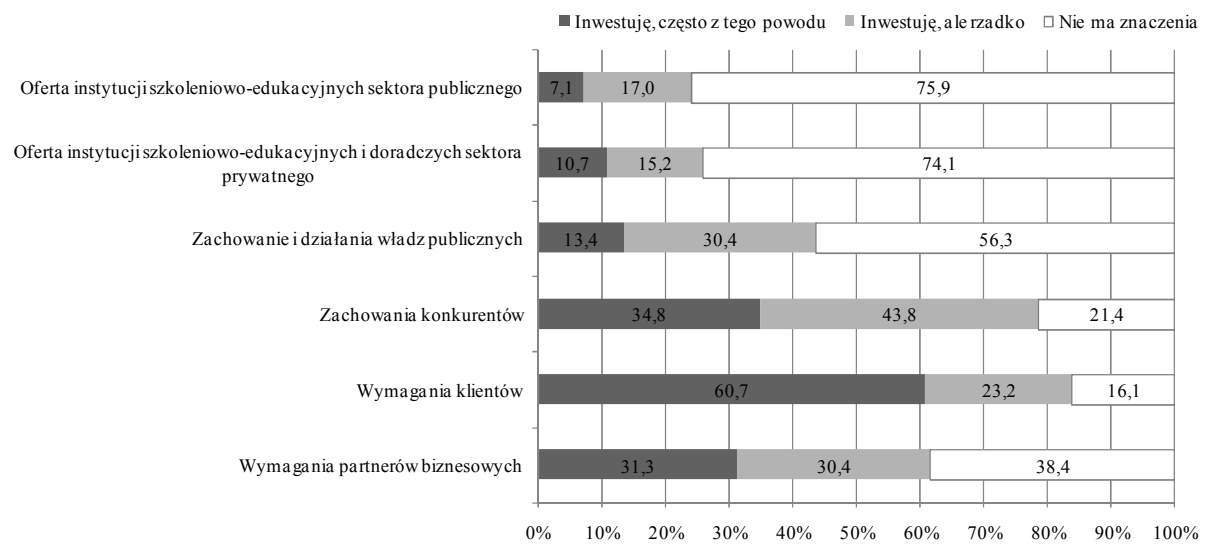

Źródło: opracowanie własne.

Dojrzałość przedsiębiorstwa do aktualnych warunków gospodarowania, można również określić poprzez identyfikację zapotrzebowania na wiedzę oraz umiejętności związane z jej użytkowaniem, zgłaszane przez pracowników. Miernik ten odzwierciedla również cechy lokalnych środowisk przedsiębiorczości, których częścią składową są pracownicy przedsiębiorstw mobilni na rynku pracy. Spośród 83 firm, które zatrudniają pracowników, prawie 80\% respondentów przyznało, że to właśnie pracownicy ich przedsiębiorstw dostrzegają potrzebę pogłębiania swojej wiedzy i kwalifikacji zawodowych, często determinując zarządzających do podejmowania takich działań.

Właściciele przedsiębiorstw i menedżerowie badanych firm podkreślają także, że w wyniku dotychczasowego wzrostu poziomu wiedzy, kompetencji pracowników oraz innowacji w organizacji, zmieniła się także ich pozycja rynkowa. W zdecydowanej większości czynniki te determinują przedsiębiorców do większego zróżnicowania oferty swoich produktów (57\%), praktycznie nie wpływając na pogłębienie specjalizacji. Niewątpliwie jest to konsekwencją poczucia dużej niepewności na rynku. Wyniki badań potwierdzaja jednak, że wraz z upływem czasu, przedsiębiorcy budując sieci powiązań i relacje z otoczeniem, jednocześnie socjalizują poziom swojego ryzyka. Pozwala to na podjęcie wyzwań, na rzecz zwiększenia specjalizacji swojej działalności. Niejednokrotnie strategia taka skutkuje ograniczeniem popytu na lokalnym rynku, zmuszając do

Europejskiej, dla podnoszenia konkurencyjności i innowacyjności małych i średnich przedsiębiorstw. Studium porównawcze województwa łódzkiego i regionu Umbrii (Włochy), projekt realizowany pod kierownictwem dr M. Słupińskiej, nr: N N114 143240. Autor uczestniczy w realizacji tych badań. 
Rysunek 7. Odpowiedź respondentów na pytanie: Czy pracownicy przedsiębiorstwa sami dostrzegaja potrzebę pogłębiania swojej wiedzy i kwalifikacji zawodowych?
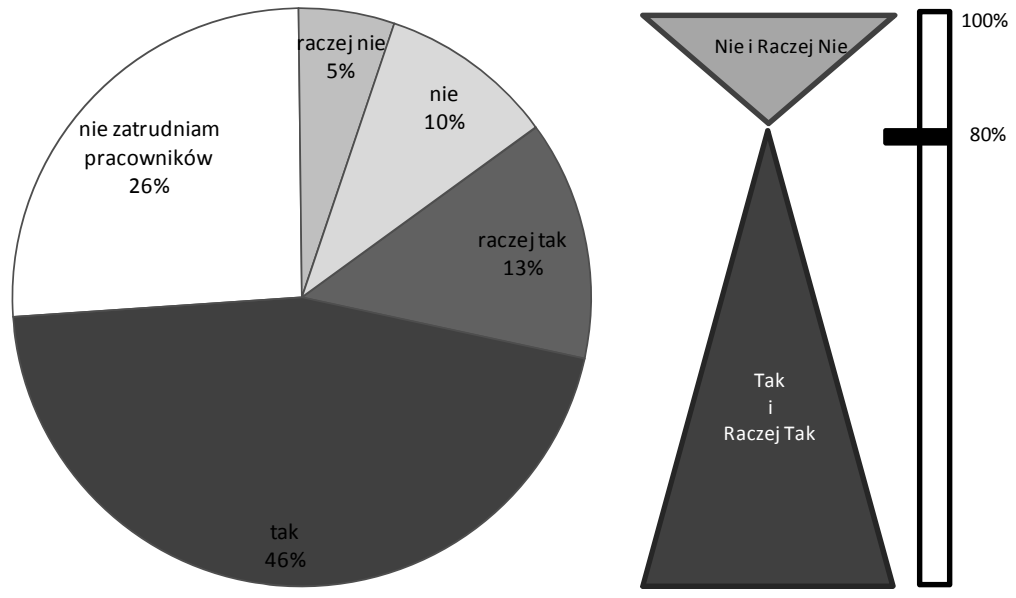

Źródło: opracowanie własne.

konkurowania na rynkach zewnętrznych. $Z$ perspektywy wzmacniania procesów doskonalenia to korzystne zjawisko, choćby poprzez zwiększanie rozmiarów egzogenicznych czynników rozwoju (klasyczna teoria bazy ekonomicznej). W latach 2001-2002 specjalizacja była bardzo rzadkim wyzwaniem podejmowanym przez przedsiębiorstwa sektora produkcyjnego, choć już wówczas nieliczni respondenci zwracali uwage, że orientacja taka może być dla nich czynnikiem sukcesu. Obecny poziom dojrzałości lokalnych środowisk przedsiębiorczości w regionie łódzkim, znacznie częściej pozwala respondentom specjalizować się w swoich obszarach działalności (łącznie 43\% wskazań). 19\% badanych przyznaje, że dzięki zwiększaniu się zasobów wiedzy, kompetencji i innowacji w działalności przedsiębiorstw, dochodzi przede wszystkim do specjalizacji działań i nie wpływa to na zwiększenie zróżnicowania oferty. Podobna część badanych $24 \%$ podejmuje wyzwania dotyczące strategii specjalizacji, jednocześnie zabezpieczając się rozszerzaniem profilu swojej działalności. 
Rysunek 8. Konsekwencje inwestycji w wiedzę i kapitał ludzki w zakresie formułowania strategii „przedsiębiorstw opartych na wiedzy”

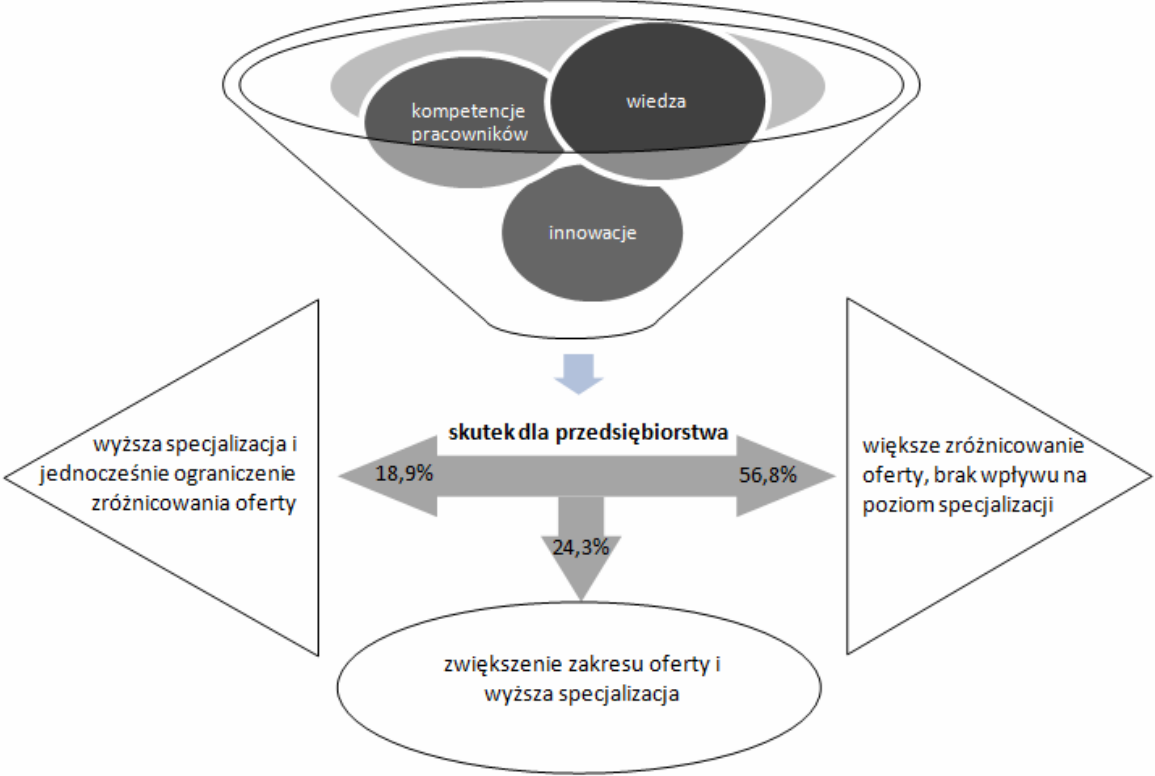

Źródło: opracowanie własne.

Interesujące są również odpowiedzi respondentów, dotyczące identyfikacji kluczowych czynników inicjowania procesów zmian i innowacji w przedsiębiorstwach. Inwestycje w kapitał ludzki wymagają nakładów finansowych, które dla $55 \%$ respondentów są kluczową determinantą innowacyjności przedsiębiorstwa. Około $47 \%$ badanych stwierdza, że największym wyzwaniem w zakresie budowania potencjału konkurencyjnego jest dysponowanie wiedzą i pomysłem na innowacje. Co ciekawe znaczna część tych samych respondentów (ok. 62\%) podkreśla także, iż najważniejszą determinantą inicjowania procesów zmian, innowacji w przedsiębiorstwie jest dostępność środków finansowych. Odpowiedzi takiej udzieliły niemal wyłącznie przedsiębiorstwa mikro i małe (odpowiedziały podobnie jedynie dwie firmy zatrudniające od 50-249 osób). Z jednej strony potwierdza to tezę, że innowacja jest kosztowna, z drugiej strony dowodzi o stosunkowo niskim poziomie zaangażowania w kooperację w lokalnym środowisku przedsiębiorczości, lub niezobowiązujących formach i przedmiotach realizacji tego typu współpracy. Poziom tej współpracy nie pozwala jeszcze na podejmowanie w szerokiej skali skutecznych działań, w zakresie pozyskiwania zewnętrznych źródeł finansowania działalności gospodarczej. Wnioski takie potwierdza fakt dostępności znacznego zabezpieczenia finansowego w okresie realizacji badań w Polsce, w ramach różnorodnych instrumentów o charakterze 
pomocy publicznej, związanych ze wsparciem innowacyjności, innowacji i transferu technologii dla beneficjentów działających w ramach zdefiniowanych sieci porozumień, w szczególności klastrów. Wnioskowanie takie per analogia potwierdzają także obserwacje sytuacji w innych krajach, gdzie inwestycje w wiedzę i kapitał ludzki są znacznie bardziej powszechne oraz mają usystematyzowany charakter. Dobrym przykładem mogą być Niemcy, gdzie bardzo dobrze zorganizowane środowiska przedsiębiorczości, zwłaszcza wokół koncernów samochodowych i przedsiębiorstw branży lotniczej, dbają o ścisłe kontakty z publiczną sferą $B+R$, skąd obok dostępu do wiedzy pozyskują znaczne środki finansowe (na przykład w ramach Programów Ramowych UE). Główne wyzwania strategii rozwojowych tych środowisk, dotyczą kwestii merytorycznych i sposobów pozyskiwania wiedzy i jej ochrony. W znacznej mierze realizowane jest to na podstawie kontraktów w jednostkach sektora publicznego ${ }^{24}$.

Rysunek 9. Odpowiedź respondentów na pytanie: Czy uważacie Państwo, że zdobycie pomysłu - wiedzy w zakresie możliwych innowacji w przedsiębiorstwie jest największą trudnością w zakresie budowania przewagi konkurencyjnej?

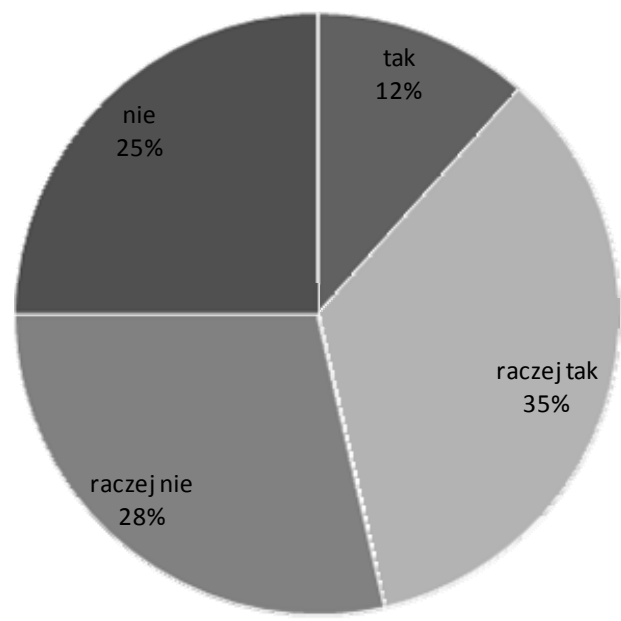

Źródło: opracowanie własne.

${ }^{24}$ Sytuacja ta z perspektywy sektora publicznego stała się wręcz kłopotliwa (ujawniły się negatywne efekty zewnętrzne), ponieważ uczelnie muszą bronić się przed „wyzyskiem” ze strony sektora prywatnego, często starając się bronić swojej własności intelektualnej na drodze sądowej. Źródło: na podstawie informacji uzyskanej przez Ewelinę Wronkę (specjalista w Biurze Programów Badawczych i Strukturalnych Uniwersytetu Lódzkiego) podczas wizyty studyjnej na Politechnice Berlińskiej w lipcu 2013. 
Warto zauważyć, że znaczna grupa respondentów wskazuje brak trudności ze znalezieniem pomysłu na wprowadzenie innowacji i zmian w przedsiębiorstwie. Zdecydowanie częściej postawę tę przejawiają ci przedsiębiorcy, których pracownicy sami dostrzegają potrzebę pogłębiania swojej wiedzy i kwalifikacji zawodowych (62\% wskazań). Można oczekiwać, że są oni z jednej strony inicjatorami zmian, z drugiej strony postawy tego typu tworzą odpowiedni klimat, środowisko i atmosferę do wprowadzania innowacji w przedsiębiorstwie.

Rysunek 10. Odpowiedź respondentów na pytanie: Czy uważacie Państwo, że dostępność środków finansowych jest najważniejszą determinantą inicjowania procesu zmian, innowacji w przedsiębiorstwie

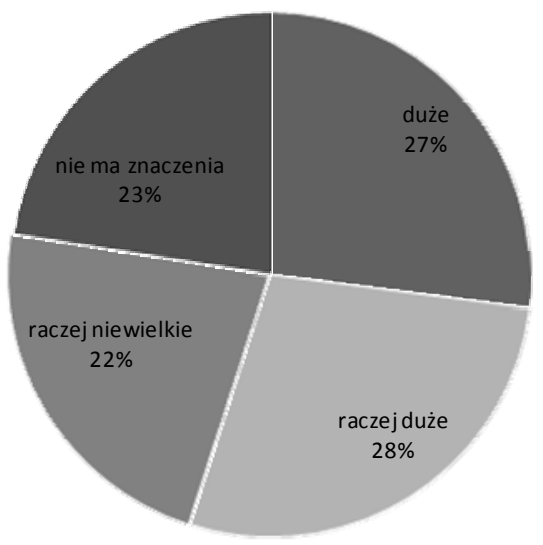

Źródło: opracowanie własne.

Respondenci postulujący, że to dostępność środków finansowych jest najważniejszą determinantą inicjowania procesu zmian i innowacji w przedsiębiorstwie wskazują że wzrost poziomu wiedzy i kompetencji pracowników skutkuje najczęściej jedynie rozszerzeniem zakresu oferty produktów (57\%). Jedynie nieliczna grupa badanych w tej sytuacji wskazywała, że dzięki środkom finansowym dochodzi do pogłębiania specjalizacji w prowadzonej działalności i jednocześnie ograniczania oferty. 


\section{Zaangażowanie małych i średnich przedsiębiorstw w inwestycje w kapitał ludzki}

\subsection{Percepcja potrzeb inwestycyjnych w kapitał ludzki}

Można stwierdzić, iż badani przedsiębiorcy (88\%) nie mają wątpliwości, że inwestycje w kapitał ludzki determinują rozwój ich firm. Przedsiębiorcy deklarują ( $78 \%$ badanych), że inwestowali by kapitał ludzki również wówczas gdyby jedynym źródłem finansowania tych inwestycji były środki własne. Tym samym przedsiębiorcy zaprzeczają stwierdzeniu $(70 \%)$, że inwestycje te są efektem dostępności środków europejskich na ich finansowanie lub aktualnej mody. $\mathrm{Z}$ drugiej strony nie są także traktowane wyłącznie jako element wewnętrznego systemu zarządzania firma, stanowiący jedynie składową systemu motywacji.

Rysunek 11. Odpowiedź respondentów na pytanie: Czy uważaja Państwo, że inwestycje w kapitał ludzki w przedsiębiorstwie determinuja jego rozwój

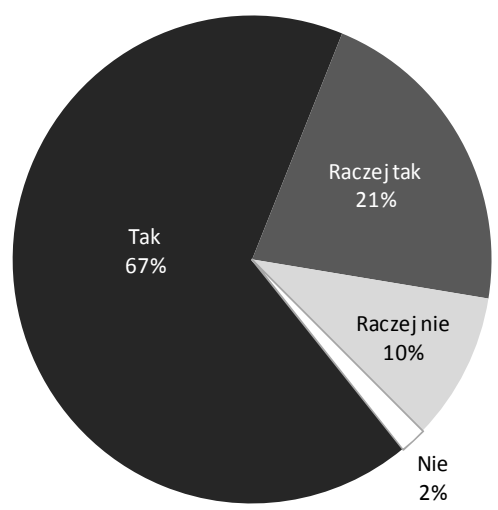

Źródło: opracowanie własne. 
58 Zdolność absorpcji wiedzy i percepcja roli kapitału ludzkiego...

Rysunek 12. Odpowiedź respondentów na pytanie: Czy inwestowaliby Państwo w kapitał ludzki w swoim przedsiębiorstwie w przypadku braku możliwości pozyskiwania zewnętrznych źródeł finansowania lub dostępności bezpłatnych lub tanich projektów szkoleniowych, edukacyjnych, kursów itp.?

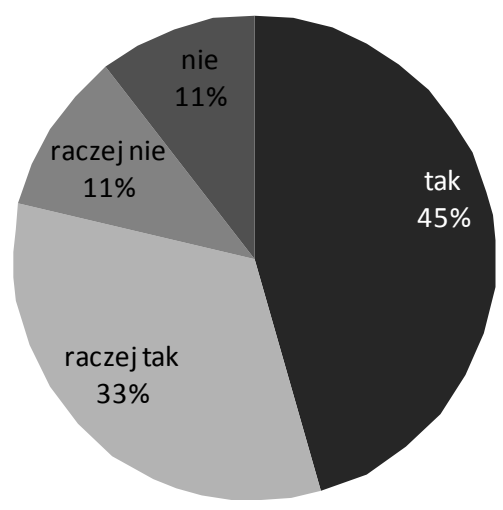

Źródło: opracowanie własne.

Rysunek 13. Odpowiedź respondentów na pytanie: Czy oceniacie Państwo, że inwestycje w kapitał ludzki w Państwa przedsiębiorstwie to głównie efekt dostępności środków europejskich na ich finansowanie lub aktualnej mody?

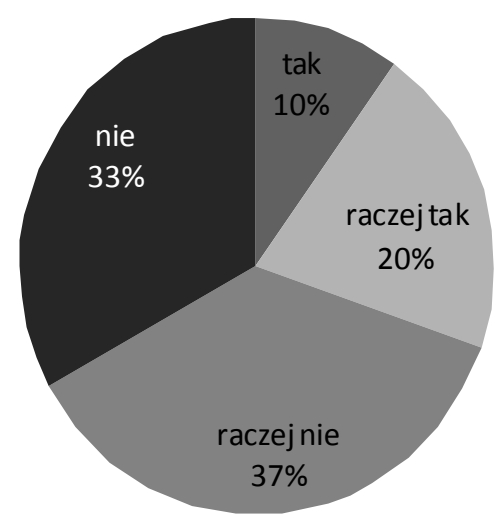

Źródło: opracowanie własne. 
Rysunek 14. Odpowiedź respondentów na pytanie: Czy uważają Państwo, że inwestycje w kapitał ludzki w przedsiębiorstwie stanowia jedynie element systemu motywacji pracownika i nie mają większego wpływu na rozwój firmy?

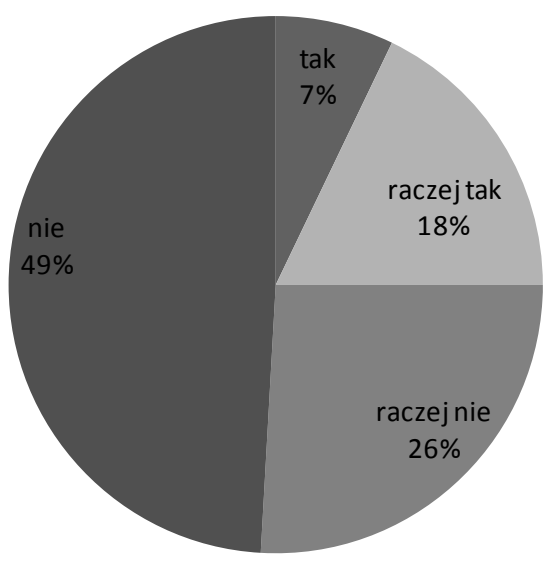

Źródło: opracowanie własne.

Wśród najbardziej konkurencyjnych przedsiębiorstw w regionie łódzkim, które można nazwać liderami rozwoju, 57\% przyznało, że na bieżąco angażuje się w inwestycje w kapitał ludzki w postaci dofinansowywania szkoleń, kursów, staży, wyjazdów, edukacji własnej czy pracowników, powodujących wzrost kompetencji. Systematyczne działania w każdym miesiącu podejmuje w tym zakresie $8 \%$ badanych. Są to $\mathrm{w}$ takiej samej ilości zarówno przedsiębiorstwa produkcyjne, jak i usługowe. $36 \%$ badanych stwierdziło, że ich działalność w zakresie podwyższania wartości kapitału ludzkiego ma charakter zdefiniowanej $\mathrm{w}$ przedsiębiorstwie polityki edukacyjno-szkoleniowej. $23 \%$ badanych $\mathrm{z}$ tej grupy stwierdziło, iż są to działania zaplanowane, systematyzowane w dłuższym okresie czasu i, co ważne, zasady tej polityki znane są pracownikom przedsiębiorstwa. Polityka szkoleniowo-edukacyjna realizowana jest $\mathrm{w}$ różnorodnych formach. W $60 \%$ stanowią ją działania, dotyczące organizacji praktyk zawodowych i współpracy ze szkołami różnych typów, w zakresie kształcenia pracowników. Sytuacja ta jest konsekwencją $\mathrm{z}$ jednej strony wewnętrznych potrzeb przedsiębiorstwa, $\mathrm{z}$ drugiej strony natomiast polityki jednostek edukacyjnych $\mathrm{w}$ regionie, poszukujących partnerów gospodarczych lub wpisujących $\mathrm{w}$ pro- 
60 Zdolność absorpcji wiedzy i percepcja roli kapitału ludzkiego...

gramy kształcenia obowiązek odbywania praktyk zawodowych, zgodnych z kierunkiem kształcenia ${ }^{25}$.

Rysunek 15. Częstotliwość dokonywania inwestycji we wzrost wartości kapitału ludzkiego w badanych przedsiębiorstwach

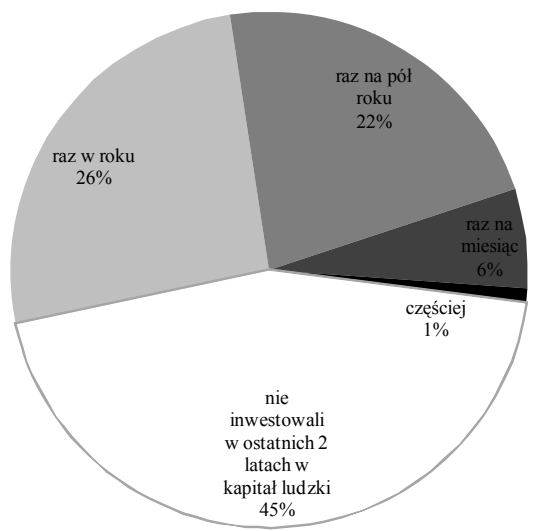

Źródło: opracowanie własne.

Rysunek 16. Zakres realizacji polityki szkoleniowo-edukacyjnej w \%

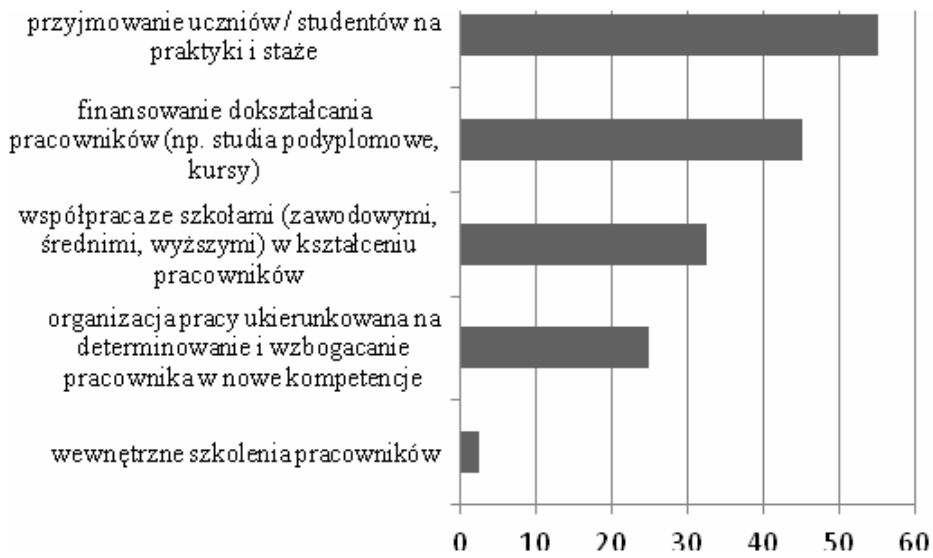

Źródło: opracowanie własne.

${ }^{25}$ Przykładem są działania Uniwersytetu Łódzkiego, a w szczególności Wydziału Ekonomiczno-Socjologicznego, gdzie liczba studentów odbywających praktyki zawodowe (kierunkowe) wzrosła z ok. 20\% w roku 2007 do $100 \%$ w roku 2009 i kolejnych 2010, 2011, 2012, 2013. (dane z roku 2007 mają charakter szacunkowy na podstawie obliczeń Wydziałowego Kierownika Zawodowych Praktyk Studenckich Wydziału Ekonomiczno-Socjologicznego UŁ). 
6\% badanych wskazuje ponadto, że prowadzi politykę szkoleniowoedukacyjną, w postaci przyjmowania uczniów i studentów na praktyki lub wykorzystując inne formy współpracy ze szkołami, która nie wiąże się bezpośrednio z ponoszeniem wydatków na ten cel.

\subsection{Zakres polityki rozwoju kapitału ludzkiego w innowacyjnych środowiskach przedsiębiorczości w aspekcie podmiotowym i finansowym}

Wyniki przeprowadzonych badań pozwalają jednoznacznie potwierdzić przekonanie przedsiębiorców, iż ich zaangażowanie finansowe i wysiłek organizacyjny na tle inwestowania w kapitał ludzki, jest niezbędny dla utrzymania pozycji konkurencyjnej na rynku. Istnieje jednak kilka dylematów, których rozstrzygnięcie jest istotne z punktu widzenia kształtowania warunków wspierania inwestycji w kapitał ludzki na poziomie regionalnym:

- Z punktu widzenia efektywności i zdolności innowacyjnych, inwestycje w kapitał ludzki powinny być finansowane z budżetu publicznego, czy ze środków własnych przedsiębiorstw?

- Kiedy powinna kończyć się rola sektora publicznego, w zakresie odpowiedzialności za inwestycje w człowieka, z perspektywy kształtowania optymalnych warunków dla realizacji polityki rozwoju na poziomie regionu?

- Czy inwestycje w kapitał ludzki należy traktować jedynie jako element budowania wartości przedsiębiorstwa (zasób wewnętrzny przedsiębiorstwa)?

Badanie to oczywiście nie daje jednoznacznych odpowiedzi, ukazuje jedynie punkt widzenia przedsiębiorcy, który może stanowić podstawę kolejnych interwencji publicznych. Jedynie $16 \%$ badanych stwierdza kategorycznie, że inwestowanie w rozwój kapitału ludzkiego w przedsiębiorstwie jest nieopłacalne, nie oznacza to jednak, że respondenci negują w ogóle zasadność podwyższania wartości zasobów tego kapitału, jako czynnika rozwoju. 16\% spośród badanych przedsiębiorców uważa, że w obecnych warunkach znacznie skuteczniej można pozyskiwać wiedzę i już wykształconych (wykwalifikowanych) pracowników z zewnątrz (na rynku). Minimalizują tym samym koszty prowadzenia działalności gospodarczej o tę kategorię wydatków. Kolejnych 19\% respondentów przychyla się do takiego stanowiska, choć opinia ta nie jest już tak kategoryczna. Można zatem podsumować, iż 35\% badanych (w tym 69\% stanowią firmy jednoosobowe i mikroprzedsiębiorstwa) oczekuje od otoczenia, że znajdzie tu kapitał ludzki o odpowiednich właściwościach, pozwalających generować przedsiębiorstwu przewagi konkurencyjne. Niestety, na obecnym poziomie rozwoju środowiska, 71\% spośród tej grupy badanych przedsiębiorców stwierdza, że rynek $\mathrm{w}$ regionie łódzkim nie oferuje jeszcze odpowiednio przygotowanych 
zasobów kapitału ludzkiego, dlatego chcąc być konkurencyjnymi, zmuszeni są samodzielnie inwestować w pracowników. Jednocześnie 50\% tej grupy stwierdza także, że rynek nie jest w stanie zaopatrzyć pracowników w unikalne kwalifikacje, właściwe konkretnemu przedsiębiorstwu. W tym celu konieczne są więc samodzielne nakłady instytucji na ,unikalne" kwalifikacje pracowników i zarządzających. Sami przedsiębiorcy muszą ostatecznie inwestować w pracowników, którzy pozwolą im w konsekwencji wygenerować przewagi konkurencyjne. Opinię taką prezentują w 68\% przedsiębiorstwa średnie i małe (w równej wielkości).

$\mathrm{Z}$ drugiej jednak strony, nie wszyscy przedsiębiorcy oczekują tego, że rynek zaopatrzy ich w kapitał ludzki o unikalnych właściwościach. 46\% badanych uważa, że nie trzeba dysponować specyficznymi zasobami kapitału ludzkiego, aby być konkurencyjnym. Ważne jednak, aby jego wartość była odpowiednio wysoka (choć „standardowa”). Wyniki badań ujawniają zatem, iż potrzeby innowacyjnych przedsiębiorstw są zróżnicowane pod względem oczekiwań związanych z dostępnością kapitału ludzkiego i poziomem jego zainwestowania wyposażenia $\mathrm{w}$ wiedzę podstawową, zaawansowaną czy innowacyjną ${ }^{26}$. Brak jest zatem możliwości ustalenia apriori „złotej proporcji”, na obszarze inwestycji w zróżnicowane zasoby kapitału ludzkiego. W każdym regionie konieczne są indywidualne diagnozy strategiczne, w celu określenia ram inwestycji w wiedzę na różnych poziomach - regionalna identyfikacja luk wiedzy. W warunkach gospodarki opartej na wiedzy stanowi ona największą część luki strategicznej, której eliminacja jest warunkiem skutecznej realizacji polityki rozwoju regionu.

Przedsiębiorcy wskazuja, że najczęściej nie wiedzą jaką część zysku generują inwestycje w kapitał ludzki. 75\% respondentów przyznaje, że angażując się we wzrost wartości kapitału ludzkiego nie potrafi oszacować efektywności swych działań, w ujęciu finansowym zysków z tego tytułu ${ }^{27}$. Sytuacja taka z pewnością determinuje występowanie stosunkowo dużego stopnia asekuracji i powściagliwości w zakresie tych inwestycji.

Pamiętając, że celem nadrzędnym jest dobrostan całej społeczności regionu, istnieje wiele wyzwań dla sektora publicznego zarówno w zakresie promowania, jak i zaangażowania organizacyjno-finansowego $\mathrm{w}$ proces podwyższania wartości kapitału ludzkiego. Tym bardziej, że bogata w wiedzę społeczność regionu determinuje korzystne warunki do lokalizacji przedsiębiorstw, które z różnych przyczyn nie chcą inwestować w wartości niematerialne, uciekając się w szczególności do internalizacji wartościowego kapitału ludzkiego z otoczenia.

${ }^{26}$ A. Nowakowska, Z. Przygodzki, M. Sokołowicz, Region $w$ gospodarce opartej na wiedzy. Kapitat ludzki, innowacje, korporacje transnarodowe, Wydawnictwo Difin, Warszawa 2011, s. 18-19.

${ }_{27}$ Jest to również ogromne wyzwanie dla tzw. „rachunkowości wiedzy”. Szerzej: L. Niemczyk, Rachunkowość zasobów wiedzy przedsiębiorstwa, Gospodarka Narodowa, nr 5-6/2011, s. $105-122$. 
Respondenci dokonali także oceny otoczenia instytucjonalnego innowacyjnego środowiska przedsiębiorczości, w kontekście roli jaką pełni w procesie budowania wartości kapitału ludzkiego. Należy pamiętać, że opinie na ten temat formułowane są przez respondentów w czasie, kiedy znaczne środki finansowe z funduszy unijnych zostały ukierunkowanie na wzmacnianie kapitału ludzkiego, również w perspektywie stosunkowo wąskich kwalifikacji. Wiedza ta pozwala z większym prawdopodobieństwem wnioskować, że ewentualna krytyka systemu wsparcia inwestycyjnego kapitału ludzkiego, dotyczy głównie kontekstu efektywności alokowanych środków, a nie braku dostępności kapitału. Badania realizowane równolegle, oparte na studiach przypadków w wybranych krajach europejskich pozwalają stwierdzić, iż najczęściej nieefektywność w tej dziedzinie determinowana jest niedopasowaniem oferty do potrzeb lokalnego rynku pracy, brakiem wiedzy na temat potrzeb lokalnego środowiska, brakiem regionalnych systemów monitorowania kluczowych dla regionu branż i specjalizacji $^{28}$.

Jaki jest zatem obraz przygotowania otoczenia przedsiębiorcy $\mathrm{w}$ regionie łódzkim do inwestowania w kapitał ludzki? Wnioski z przeprowadzonych badań ${ }^{29}$ ukazują krytyczną ocenę tego stanu. Ponad 54\% respondentów podkreśla, że brak jest odpowiedniej oferty instytucji działających w obszarze inwestycji w wiedzę i kapitał ludzki w regionie. Ocena ta jest odpowiednio negatywna zarówno w odniesieniu od instytucji sektora prywatnego, jak i publicznego. Dodatkowo ponad $34 \%$ badanych podkreśla, że nawet jeśli istnieje tego typu oferta, to usługi są trudno dostępne $\mathrm{z}$ uwagi na ich niewielką podaż, lub problemy $\mathrm{w}$ dotarciu do informacji na ich temat. Jedynie 5\% badanych przedsiębiorstw jednoznacznie pozytywnie ocenia pod tym względem przygotowanie środowiska.

Niska ocena jakości otoczenia przedsiębiorstw, wynika zarówno z niedoskonałości podaży usług proponowanych przez sektor prywatny, jak i sektor publiczny. Respondenci zwracają uwagę, że nie są przekonani do realizowania współpracy z partnerami prywatnymi w zakresie inwestycji w kapitał ludzki. Na taką alternatywę zgodziłoby się zaledwie $30 \%$ badanych. Znamienne jest także wskazanie, w jakiego typu partnerach respondenci upatrują potencjalnych kooperantów inwestycji w wiedzę i kapitał ludzki. Po pierwsze są to firmy szkoleniowo-doradcze, w dalszej kolejności prywatne instytuty badawcze i dopiero w trzeciej i czwartej kolejności bezpośredni kooperanci biznesowi i konkurenci,

${ }^{28}$ Szerzej: Regionalny wymiar polityki rozwoju kapitalu ludzkiego. Przykład Włoch, Wielkiej Brytanii, Niemiec i Polski, Z. Przygodzki (red.), Wydawnictwo Difin, Warszawa 2013.

${ }^{29}$ We wnioskach tych uwzględniono także wyniki badań przeprowadzonych wśród wszystkich jednostek samorządu terytorialnego w województwie łódzkim i w wybranej grupie instytucji pozarządowych działających w regionie, w obszarze inwestycji w kapitał ludzki. Badania zostały zrealizowane w ramach projektu pt. Polityka i narzędzia kreowania kapitału ludzkiego w regionie - projekt badań MNiSzW nr N N114 183938. Autorami badań są: Z. Przygodzki i J. Chądzyński. 
którzy posiadają lub byliby zainteresowania tym samym zakresem kwalifikacji i kompetencji. Taki układ wskazań jest dość charakterystyczny dla środowisk przedsiębiorczości, będących na niskim poziomie zorganizowania (dysponujących niskim poziomem zasobów kapitału społecznego).

Rysunek 17. Ocena oferty instytucji publicznych i prywatnych w regionie łódzkim, w zakresie możliwości wsparcia rozwoju kapitału ludzkiego
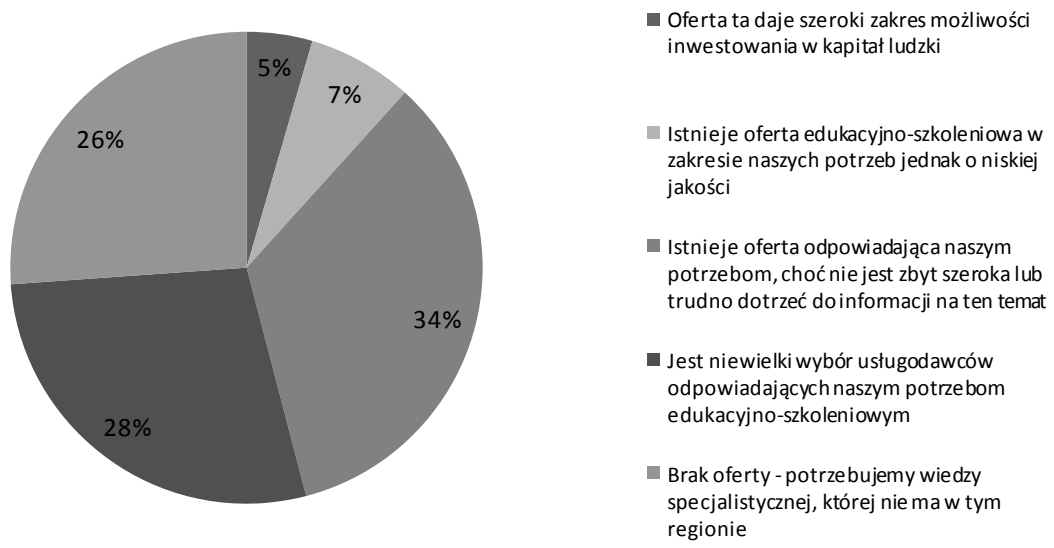

Źródło: opracowanie własne.

Ocena podmiotów publicznych, jako jednostek ułatwiających inwestowanie w kapitał ludzki jest nieco korzystniejsza, ponieważ w tym przypadku ok. $40 \%$ respondentów dokonało takiego wskazania. Przedsiębiorstwa oparte na wiedzy adresują przy tym najwięcej oczekiwań w stronę szkół wyższych. W tych jednostkach upatrują głównego partnera do współpracy. Zachowania takie, co można obserwować w polskiej rzeczywistości, są jednym z czynników determinujących reformę szkolnictwa wyższego, w kierunku organizacji tzw. Uniwersytetów III Generacji ${ }^{30}$.

${ }^{30}$ Szerzej w pracy A. Nowakowskiej, Kapitat ludzki dla potrzeb innowacyjnej gospodarki. Nowe wyzwania wobec wyższych uczelni i A. Rzeńcy, Stan i kierunki zmian na rynku ustug edukacyjnych. Przykład szkót wyższych regionu tódzkiego [w:] Kapitat ludzki w regionie łódzkim. Społeczeństwo, edukacja przestrzeń, Wydawnictwo Uniwersytetu Łódzkiego, Łódź 2014. 
Rysunek 18. Odpowiedź respondentów na pytanie: Czy podmioty prywatne działające na rynku ułatwiają lub mogłyby ułatwić Państwu inwestowanie w kapitał ludzki?

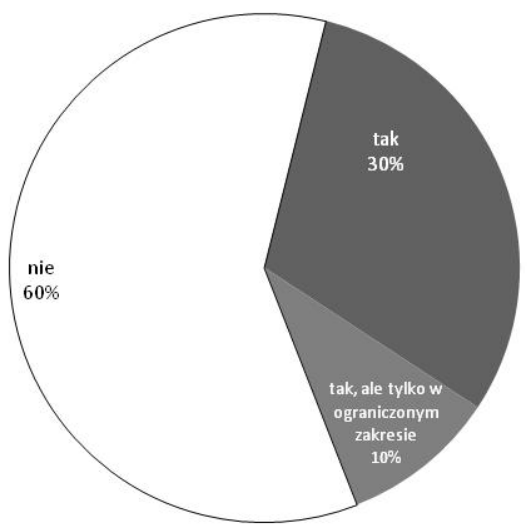

\begin{tabular}{|l|r|}
\hline $\begin{array}{c}\text { Jeśli „Tak" to jakiego typu pod- } \\
\text { mioty są lub mogłyby być dobrymi } \\
\text { partnerami w inwestowaniu w } \\
\text { kapitał ludzki wspólnie z Pań- } \\
\text { stwem }\end{array}$ & $\%$ \\
\hline $\begin{array}{l}\text { Dostawcy towarów /materiałów } \\
\text { /surowców }\end{array}$ & 17,7 \\
\hline $\begin{array}{l}\text { Podmioty tej samej branży - kon- } \\
\text { kurenci, z którymi można współ- } \\
\text { pracować }\end{array}$ & 16,1 \\
\hline Usługodawcy & 1,6 \\
\hline Firmy szkoleniowo-doradcze & 38,7 \\
\hline Prywatne instytuty badawcze & 24,2 \\
\hline Inne podmioty & 1,6 \\
\hline
\end{tabular}

Źródło: opracowanie własne

Rysunek 19. Odpowiedź respondentów na pytanie: Czy instytucje publiczne działające w regionie ułatwiają lub mogłyby ułatwić Państwu inwestowanie w kapitał ludzki?

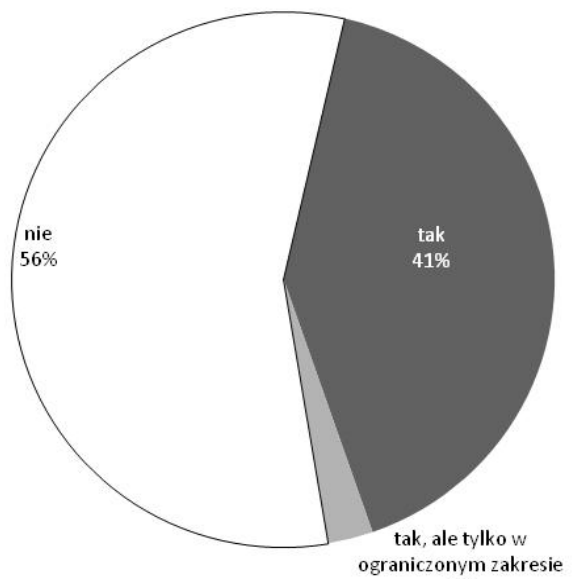

\begin{tabular}{|l|c|}
\hline $\begin{array}{c}\text { Jeśli „Tak” to jakiego typu podmioty } \\
\text { sfery publicznej } \mathrm{i} \text { w jakim zakresie } \\
\text { mogłyby być dobrymi partnerami w } \\
\text { inwestowaniu w wiedzę } \mathrm{i} \text { kapitał } \\
\text { ludzki wspólnie z Państwem }\end{array}$ & $\%$ \\
\hline Szkoły wyższe & 38,2 \\
\hline Szkoły zawodowe & 14,6 \\
\hline Szkoły średnie (technika, licea) & 14,6 \\
\hline Jednostki badawczo-rozwojowe & 13,5 \\
\hline Władze miasta/gminy/powiatu & 12,4 \\
\hline Władze regionu & 6,7 \\
\hline
\end{tabular}

Źródło: opracowanie własne. 
Podsumowując, kapitał ludzki jest jednym z ważnych czynników konkurencyjności regionu - nie ma wątpliwości co do potrzeby jego istnienia i wzmacniania. Badania potwierdzają także, że przedsiębiorcy działający w regionie łódzkim, mimo stosunkowo niskiego poziomu koordynacji działań środowiska przedsiębiorczości, ujawniają potrzeby czerpania z zasobów regionu, w celu wzmacniania swojej pozycji konkurencyjnej. W stosunkowo niewielkim stopniu, ale jednak oczekują wsparcia lub poszukują kontaktów z lokalnym środowiskiem w zakresie pozyskiwania kapitału ludzkiego i wiedzy. Nie traktują więc tych zasobów analogicznie do zasobów materialnych, jako wewnętrzne, przypisane (będące własnością), dostępne i pomnażane jedynie wewnątrz przedsiębiorstwa. Wręcz przeciwnie, co zapewne wynika z charakterystyki kapitału ludzkiego i wiedzy jako czynników produkcji, respondenci ujawniają potrzebę koordynacji działań na rzecz wspierania wartości zasobów kapitału ludzkiego i dostępności wiedzy w środowisku lokalnym.

\section{Podsumowanie - identyfikacja warunków i kierunków kształtowania polityki rozwoju kapitału ludzkiego w regionie}

Wyniki badań pozwalają szacować, że około $30 \%$ badanych przedsiębiorstw mogłoby w krótkim czasie zwiększyć znacznie swoje zaangażowanie inwestycyjne w kapitał ludzki i wykorzystanie zasobów wiedzy w regionie, działając w sprzyjających warunkach otoczenia. Charakteryzują się bowiem najważniejszą właściwością - mają świadomość potrzeby i istotności inwestowania w kapitał ludzki, brak jedynie ostatecznego przekonania, które skutkowałoby faktycznym działaniem. Owe szczególne warunki jakimi powinno odznaczać się regionalne środowisko przedsiębiorczości, nazwać można „atmosferą innowacyjną” adekwatnie do określania stosowanego przez A. Marschala. Działania podmiotów regionalnych powinny być zatem ukierunkowane na poprawę skuteczności i efektywności procesu inwestycji w kapitał ludzki w regionie, wykorzystując przede wszystkim korzyści bliskości i wiedzę o potrzebach oraz możliwościach lokalnego środowiska przedsiębiorczości. Należy pamiętać, że podstawową, realną i wykorzystywaną formą inwestowania w zasoby niematerialne, zwłaszcza obecnie w polskich warunkach, są procesy uczenia się. Uczenie się jest procesem zbiorowym, a w szerszej skali społecznym, dokonującym się, jak podkreśla R. Domański, przez wzajemne oddziaływanie i współpracę podmiotów sceny regionalnej (małe i średnie przedsiębiorstwa [MSP], władze publiczne, uczelnie wyższe, instytuty badawcze, instytucje gospodarcze, instytucje społeczne, itd.) $)^{31}$.

\footnotetext{
${ }^{31}$ R. Domański, Regionalny poziom gospodarki uczacej się, Czasopismo Geograficzne LXXI,
} 2000, s. 3-4. 
Region jest nieustannie wzbogacany w wiedzę nie tylko uprzedmiotowiona, ale także nie mniej ważną „wiedzę milczącą”, poprzez informacje i dane. Bliskość przestrzenna ma znaczenie $\mathrm{w}$ interaktywnych procesach uczenia się. „Im większa jest rola wiedzy milczącej, tym większa jest waga bliskości partnerów, uczestniczących w wymianie wewnątrz systemu lokalnego"32. Dynamika uczenia się odzwierciedla zbiorową zdolność aktorów, do zmiany swoich zachowań w funkcji transformacji, której jest poddane środowisko. Dzięki tej dynamice możliwa jest równowaga między relacjami, opartymi z jednej strony na strategii konkurencji, a $\mathrm{z}$ drugiej na strategii współdziałania. Zdolność indywidualnego i zbiorowego uczenia się jest niezwykle istotna, z punktu widzenia budowania innowacyjnego rozwoju regionu.

Badania ujawniają że w przedsiębiorstwach innowacyjnych istnieje znaczny potencjał w obszarze skłonności przedsiębiorstw do inwestowania w wartości niematerialne. Ponad $80 \%$ badanych docenia kluczową rolę ludzi w budowaniu wartości przedsiębiorstwa oraz ważną rolę inwestowania w zasoby ludzkie. Mimo to, dotychczas jedynie $36 \%$ respondentów prowadzi systematyczne działania w tym zakresie, które nazywa polityką szkoleniowo-edukacyjną. Wiedza i kwalifikacje stanowią dla większości badanych ważne kryterium oceny, brane pod uwage przy awansie zawodowym. Jedynie $36 \%$ respondentów twierdzi, że to inne czynniki decydują o awansie. Innymi słowy, przedsiębiorstwa oparte na wiedzy mają świadomość znaczenia wiedzy i kapitału ludzkiego w budowaniu przewag konkurencyjnych, jednak nie w pełni można potwierdzić hipotezę (H1), ponieważ tylko w ograniczonym zakresie i nieznaczna ilość przedsiębiorstw prowadzi obecnie świadomą politykę inwestycyjną, mającą na celu wzrost poziomu wiedzy i kapitału ludzkiego. Jest to zatem wyzwanie dla polityki regionalnej, aby wykształcić i wypromować mechanizmy determinujące lokalne podmioty do inwestycji w wiedzę $\mathrm{i}$ kapitał ludzki.

Badania wskazują, że potrzeby „przedsiębiorstw opartych na wiedzy” są zróżnicowane jeśli chodzi o oczekiwania, związane z dostępnością kapitału ludzkiego i poziomem jego zainwestowania. Respondenci potwierdzają w większości, że pozyskiwanie wiedzy specjalistycznej i kapitalu ludzkiego z otoczenia jest efektywniejsze i korzystniejsze dla przedsiębiorstw niż inwestowanie w wiedzę ze środków własnych, ponieważ równie skutecznie umożliwia osiaganie przewag konkurencyjnych. Jednak uogólniając wniosek w kontekście hipotezy (H2), aktualny stan rozwoju (organizacji, zdolności) lokalnych środowisk przedsiębiorczości nie pozwala na przyjęcie takiej strategii działania i zmusza przedsiębiorców do indywidualnych inwestycji w tym zakresie. Niestety mają one często asekuracyjny charakter i niewielki rozmiar. Ciągle jeszcze ponad połowa

${ }^{32}$ R. Domański, A. Marciniak, Sieciowe koncepcje gospodarki miast i regionów, Studia Komitetu Przestrzennego Zagospodarowania Kraju PAN, Warszawa 2003, tom CXIII, s. 21. 
instytucji wskazuje dostępność środków finansowych, jako podstawową determinantę inwestycji w kapitał ludzki - tym samym dostrzec można jeszcze stosunkowo niską priorytetyzację tego kierunku inwestowania, który często przegrywa $\mathrm{z}$ inwestycjami $\mathrm{w}$ majątek trwały. $\mathrm{Z}$ drugiej strony $3 / 4$ respondentów uważa, że należy samodzielnie inwestować w wiedzę i kapitał ludzki, ponieważ rynek regionu nie oferuje jeszcze odpowiednio przygotowanych zasobów. W tym kontekście powstaje ważne wyzwanie, dotyczące organizacji sprawnego systemu monitoringu potrzeb regionalnej gospodarki, w zakresie zasobów wiedzy i kapitału ludzkiego. Brak jest bowiem możliwości ustalenia apriori pożąananej proporcji, w obszarze inwestycji w wiedzę podstawową, zaawansowaną i innowacyjną. W każdym regionie konieczne są indywidualne diagnozy strategiczne, dla określenia zakresu inwestycji w wiedzę na różnych poziomach, w celu identyfikacji luki wiedzy ${ }^{33}$. W warunkach gospodarki opartej na wiedzy jest to największa część luki strategicznej, której eliminacja jest warunkiem skutecznej realizacji polityki rozwoju regionu.

Znaczna część przedsiębiorców podkreśla również, że dla utrzymania pożądanego poziomu konkurencyjności w regionie konieczna jest wiedza odpowiedniej jakości, nie tylko o charakterze innowacyjnym, ale także zaawansowanym i podstawowym. Można traktować ten wniosek jako apel o definicję i realizację regionalnej polityki rozwoju kapitału ludzkiego, która obecnie w Polsce funkcjonuje jedynie w szczątkowym zakresie, jako element regionalnej polityki innowacyjnej, której uzupełnieniem jest jedynie centralnie zdefiniowana polityka rozwoju kapitału ludzkiego ${ }^{34}$.

Tym niemniej nie oznacza to dezawuacji potrzeby prowadzenia regionalnej polityki innowacyjnej, zwłaszcza w porównaniu wyników badań. Prawie połowa respondentów wskazuje, że poszukuje pomysłu, aby inwestować w wiedzę o charakterze innowacyjnym, wzmacniającym poziom ich konkurencyjności. Fakt ten bezpośrednio determinuje wyzwania w zakresie skutecznych partnerstw regionalnych o charakterze prywatno-publicznym, jak i publiczno-publicznym, w kontekście budowania sieci i relacji w regionie, dla skutecznego transferu wiedzy. Jak pokazują wyniki badań zrealizowanych wśród jednostek samorządu terytorialnego oraz organizacji pozarządowych, międzysektorowa współpraca na rzecz wzrostu wartości kapitału ludzkiego w regionie pozostaje prawdziwym wyzwaniem $^{35}$.

${ }^{33}$ Szerzej: Regionalny wymiar polityki rozwoju kapitału ludzkiego. Przykład Włoch, Wielkiej Brytanii, Niemiec i Polski, Z. Przygodzki (red.), Wydawnictwo Difin, Warszawa 2013.

${ }^{34}$ Szerzej: Regionalny wymiar polityki rozwoju kapitalu ludzkiego. Przyktad Włoch, Wielkiej Brytanii, Niemiec i Polski, Z. Przygodzki (red.), Wydawnictwo Difin, Warszawa 2013.

${ }^{35}$ Szerzej w pracy J. Chądzyńskiego, Udziat podmiotów trzeciego sektora w rozwoju kapitału ludzkiego w regionie tódzkim [w:] Kapitał ludzki w regionie tódzkim. Społeczeństwo, edukacja przestrzeń, Wydawnictwo Uniwersytetu Łódzkiego, Łódź 2014. 
Wyniki badań nie dają jednak podstaw do potwierdzenia hipotezy (H3) przedsiębiorstwa oparte na wiedzy działajace $w$ regionie tódzkim maja większa skłonność i zdolność do integracji lokalnych środowisk przedsiębiorczości. Teoretycznie można by oczekiwać, iż przedsiębiorstwa oparte na wiedzy będą upatrywać we współpracującym środowisku przede wszystkim ograniczenia kosztów transakcyjnych oraz socjalizacji ryzyka prowadzenia działalności. Będą również nawiązywać relacje, aby pozyskiwać wiedzę sektorów pokrewnych, w celu kreowania własnych innowacji. $Z$ pewnością przedsiębiorstwa innowacyjne są cenne dla gospodarki lokalnej, ponieważ wpływają miedzy innymi na poziom dochodowości regionu oraz innowacyjność całego środowiska przedsiębiorczości, dzięki zjawiskom dyfuzji wiedzy. Determinują powstawanie innowacji w regionie oraz procesy rozprzestrzeniania się wiedzy cichej, abstrahując od stopnia sprawności tego zjawiska na skutek stopnia integracji środowiska. Wyniki badań nie dały jednak jednoznacznych odpowiedzi czy przedsiębiorstwa oparte na wiedzy, funkcjonujące w obecnych warunkach w regionie, będące na aktualnym poziomie rozwoju, determinują integrację lokalnych systemów produkcyjnych. Wzmacnianie spójności środowisk przedsiębiorczości w regionie łódzkim (w szczególności determinowanie organizacji klastrów), nie powinno obecnie odbywać się jedynie poprzez wzmacnianie potencjału innowacyjnego przedsiębiorstw. Wymagane jest wykorzystanie innych czynników wzmacniających integrację lokalnych systemów produkcyjnych, niekoniecznie bezpośrednio związanych $\mathrm{z}$ poziomem innowacyjności przedsiębiorstw. Pożądany wzrost innowacyjności podmiotów gospodarczych, z dużym prawdopodobieństwem będzie konsekwencją zmian organizacji lokalnych środowisk przedsiębiorczości.

Przyjmując tezę, że wzrost poziomu specjalizacji przedsiębiorstw korzystnie wpływa na poziom organizacji środowisk przedsiębiorczości, można wskazać następujące konsekwencje wyboru takiej strategii działania, w kontekście zmiany zasięgu rynkowego prowadzonej działalności. Po pierwsze, specjalizacja może determinować konieczność rozszerzenia zasięgu rynkowego działalności przedsiębiorstwa o rynki ponadregionalne na skutek: (a) niedostatecznego popytu lokalnego na „unikalny” produkt lub (b) produkt oferowany w większej ilości po korzystniejszej cenie, z powodu wystąienia korzyści skali, dzięki specjalizacji działalności. Jest to najkorzystniejsza sytuacja dla regionu zarówno z perspektywy najwyższych zdolności do kreowania współpracy i tworzenia silnych innowacyjnych środowisk przedsiębiorczości, jak i ich zdolności innowacyjnych. Po drugie, specjalizacja może determinować reorganizację regionalnego rynku zbytu. W tym przypadku odsłaniają się potencjalne pola współpracy $\mathrm{z}$ innymi przedsiębiorcami $\mathrm{w}$ branży, $\mathrm{w}$ związku $\mathrm{z}$ brakiem bezpośredniej konkurencji na rynku lokalnym. Jednak istniejąca, silna konkurencja między przedsiębiorcami osłabia skłonność do podejmowania współpracy, lub zakres tej współpracy ogranicza się to niewielkiej liczby podmiotów. Sytuacja ta w ograni- 
czonym zakresie wpływa na wzrost zdolności innowacyjnych regionu zarówno z perspektywy niewielkich skłonności do budowania sieci, relacji i organizacji środowiska przedsiębiorczości, jak i ograniczonego wpływu środowiska zewnętrznego na kształtowanie konkurencyjności lokalnego systemu produkcyjnego.

Rysunek 20. Zachowania w zakresie zasięgu rynku i produktu przedsiębiorstw opartych na wiedzy w regionie łódzkim

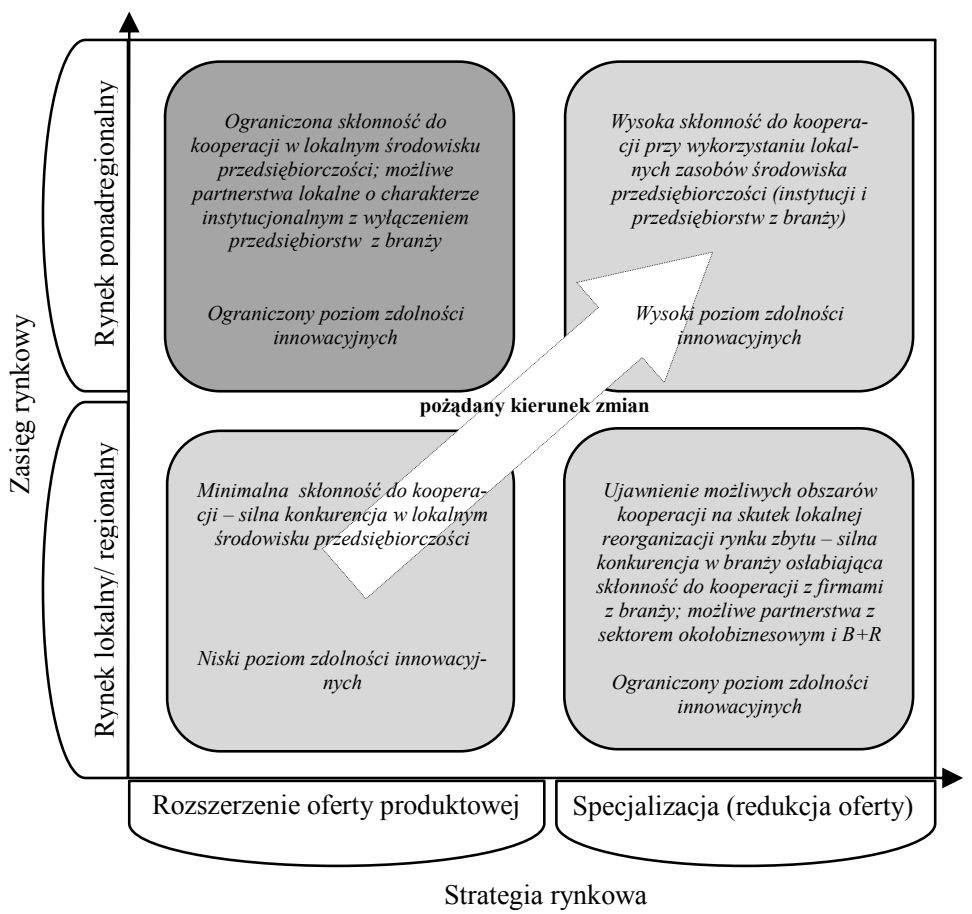

Źródło: opracowanie własne.

Trzecia alternatywa to sytuacja, kiedy inwestycje w wiedzę i kapitał ludzki w przedsiębiorstwie nie wywołują decyzji o specjalizacji działalności, a determinują do rozszerzenie oferty produktowej. Podstawowy zakres rynku zbytu ma charakter ponadregionalny. W tym przypadku, skłonność do kooperacji w lokalnym środowisku przedsiębiorczości, ogranicza się przede wszystkim do zawierania partnerstw $\mathrm{z}$ instytucjami otoczenia biznesu i sektora $\mathrm{B}+\mathrm{R}$. Bezpośrednia konkurencja $\mathrm{w}$ obszarze produktów ogranicza wpływ na integrację lokalnego środowiska przedsiębiorczości. Najczęstsze alianse przyjmują tutaj pionowy charakter i dotyczą zazwyczaj kontaktów handlowych związanych ze skalą pro- 
dukcji. Najmniej korzystna sytuacja, z punktu widzenia wzmacniania zdolności innowacyjnych $\mathrm{w}$ regionie występuje wówczas, gdy na skutek inwestycji w wiedzę i kapitał ludzki dochodzi jedynie do rozszerzenia oferty produktowej, a działalność przedsiębiorstwa ogranicza się jedynie do rynku regionalnego. Wówczas z jednej strony silna konkurencja uniemożliwia wręcz podejmowanie współpracy w środowisku lokalnym z drugiej strony zdolności innowacyjne przedsiębiorstwa „samotnie działającego na rynku" dodatkowo ograniczają brak relacji z otoczeniem zewnętrznym (przynajmniej ponadregionalnym).

Wyniki przeprowadzonych badań nie pozwalają dokładnie oszacować liczby przedsiębiorstw dokonujących wyboru określonych wyżej strategii działania. Można natomiast wskazać, że inwestując w wiedzę i pracowników, badani przedsiębiorcy wskazali, że znacznie częściej podejmują decyzje dotyczące rozszerzenia oferty swoich produktów, niż strategię specjalizacji działalności (ok. $57 \%$ ). Większość prowadzi przy tym działalność w oparciu o ponadregionalne rynki zbytu. Oznacza to, iż zdecydowanie częściej dochodzi do zaostrzenia konkurencji na dotychczasowych rynkach prowadzenia działalności, niż nawiązywania partnerstw na rzecz wzajemnego wspierania konkurencyjności.

Wyniki badań wskazują, że obecnie przedsiębiorstwa działające w regionie łódzkim, nawet mimo dojrzałości do inwestowania w wiedzę i kapitał ludzki, w stosunkowo niewielkim zakresie wykazują skłonność do specjalizacji swojej produkcji, tym samym, stosunkowo rzadko rozszerzają rynki swojej działalności i podejmują współpracę z innymi lokalnymi podmiotami, na rzecz zwiększenia swojej konkurencyjności. Jedynie co piąty respondent wybiera strategię specjalizacji, ograniczając jednocześnie zróżnicowanie swojej oferty. Spośród przedsiębiorstw wskazujących, że inwestycje w wiedzę determinują ich strategie działania (samą specjalizację z jednoczesnym rozszerzeniem oferty), przedsiębiorstwa oparte na wiedzy znacznie częściej wskazują, że inne podmioty mogłyby być dobrymi partnerami w zakresie inwestycji w wiedzę i kapitał ludzki $(62,5 \%)$. Chodzi tutaj głównie o instytucje otoczenia biznesu i szkoły wyższe. Wśród przedsiębiorstw, które nie nazywają siebie „opartymi na wiedzy” jedynie 37,5\% podziela taką opinię. Można zauważyć, iż deklaracja otwartości na współpracę bardzo rzadko dotyczy innych instytucji działających w branży, nawet w tak jasno określonym zakresie kooperacji, a jedynie instytucji, które nie stanowią konkurencji dla prowadzonej działalności gospodarczej.

Niewątpliwie jednak, dokonując uogólnienia i porównania z perspektywy dziesięciu lat zarówno pod kątem skłonności przedsiębiorstw do specjalizacji, jak i zaangażowania na ponadregionalnych rynkach zbytu i związanego z tym wpływu na regionalne środowiska przedsiębiorczości, lokalne systemy produkcyjne województwa łódzkiego ewoluują w pożądanym kierunku. Środowiska przedsiębiorczości w regionie łódzkim dostosowują się do warunków gospodarki opartej na wiedzy. Można natomiast postulować o szybsze tempo tych zmian, 
zwłaszcza w kontekście deklarowanej otwartości regionalnych liderów konkurencyjności na współpracę z otoczeniem lokalnym. Należy podejmować działania w zakresie polityki wspierania inwestycji w kapitał ludzki i wiedzę w perspektywie regionalnej.

\section{Bibliografia}

Boschma R., Martin R. L., The Handbook of Evolutionary Economic Geography, Edward Elgar Publishing, UK 2010.

Boschma R. A., Proximity and Innovation: A Critical Assessment, Regional Studies, Vol. 39.1, February 2005.

Domański R., Marciniak A., Sieciowe koncepcje gospodarki miast i regionów, Studia Komitetu Przestrzennego Zagospodarowania Kraju PAN, Warszawa 2003, tom CXIII.

Domański R., Regionalny poziom gospodarki uczacej się, Czasopismo Geograficzne LXXI, 2000.

Drucker P., Społeczeństwo pokapitalistyczne, Wydawnictwo Naukowe PWN, Warszawa 1999.

Hardt Ł., Ekonomia kosztów transakcyjnych - geneza i kierunki rozwoju, Wydawnictwa Uniwersytetu Warszawskiego, Warszawa 2009.

Hsaini A., Le depassement des eonomies d'agglomeration comme seules sources explicatives de l'efficacite des systemes de production territorializes, Revue d'Economie Regionale et Urbaine 2000, no.2.

Jewtuchowicz A., Terytorium $i$ współczesne dylematy jego rozwoju, Wydawnictwo Uniwersytetu Łódzkiego, Łódź 2013.

Julien P.-A., A Theory of local entrepreneurship in the knowledge economy, Edward Elgar Publishing, UK 2007.

M. Kolarz, Znaczenie wiedzy i kapitału intelektualnego we współczesnej gospodarce $i$ organizacji [w:] Kapitat ludzki $w$ dobie integracji i globalizacji, B. Kożusznik (red.), Wydawnictwo Uniwersytetu Śląskiego, Katowice 2005.

Markowska M., Zróżnicowanie europejskiej przestrzeni regionalnej w świetle koncepcji gospodarki opartej na wiedzy [w:] Gospodarka lokalna i regionalna w teorii i praktyce, D. Strahl (red.), Prace Naukowe Akademii Ekonomicznej im. O. Langego we Wrocławiu, nr 1161, Wydawnictwo Akademii Ekonomicznej im. O. Langego we Wrocławiu, Wrocław 2007.

Martinelli F., Moulaert F., Ailenei O., Territorial innovation models: a critical survey of the international literature, Institut Fédératif de Recherche sur les Économies et les Sociétés Industrielles, Intermediate report 2002.

Moulaert F., Sekia F., Territorial Innovation Models: A Critical Survey, Debates and Surveys, Regional Studies, 2003, Vol. 37.

Niemczyk L., Rachunkowość zasobów wiedzy przedsiębiorstwa, Gospodarka Narodowa, nr 5-6/2011.

Nowakowska A., Przygodzki Z., Sokołowicz M., Region w gospodarce opartej na wiedzy. Kapitat ludzki, innowacje, korporacje transnarodowe, Wydawnictwo Difin, Warszawa 2011. 
Nowakowska A., Regionalny wymiar procesów innowacji, Wydawnictwo Uniwersytetu Łódzkiego, Łódź 2011.

Ochojski A., Szczupak B., Zieliński T., Regionalne środowisko przedsiębiorczości. Problematyka badawcza [w:] Przedsiębiorczość i konkurencyjność a rozwój regionalny, A. Klasik (red.), Prace Naukowe Akademii Ekonomicznej w Katowicach, Katowice 2006.

Pietrzyk I., Konkurencyjność regionów w ujęciu Komisji Europejskiej [w:] Polityka regionalna $i$ jej rola $w$ podnoszeniu konkurencyjności regionów, M. Klamut, L. Cybulski (red.), Wrocław 2000.

Polanyi M., Tacit Knowing: Its Bearing on Some Problems of Philosophy, Reviews of Modern Physics, 34 (4), Oct. 1962.

Przybyszewski R., Kapitat ludzki w procesie kształtowania gospodarki opartej na wie$d z y$, Wydawnictwo Difin, Warszawa 2007.

Przygodzki Z., Innowacyjne środowiska przedsiębiorczości w kontekście procesów organizacji $i$ regulacji $w$ regionie [w:] Zrozumieć terytorium. Idea i praktyka, A. Nowakowska (red.), Wydawnictwo Uniwersytetu Łódzkiego, Łódź 2013.

Regionalny wymiar polityki rozwoju kapitału ludzkiego. Przykład Włoch, Wielkiej Brytanii, Niemiec i Polski, Z. Przygodzki (red.), Wydawnictwo Difin, Warszawa 2013.

Ryfkin J., Wiek dostępu. Nowa kultura hiperkapitalizmu w której płaci się za każda chwilę życia, Wydawnictwo Dolnośląskie, Wrocław 2003.

Skrzypek E., Kreatywność pracowników wiedzy i ich wpływ na innowacyjność przedsiębiorstw, materiały konferencyjne z V Konferencji Naukowej z serii „Wiedza i innowacje” pt. „Ochrona wiedzy i innowacji”, Uniwersytet Jagielloński, Kraków, 19-20 stycznia $2009 \mathrm{r}$.

Skrzypek E., Miejsce zasobów niematerialnych $w$ kształtowaniu wartości przedsiębiorstw [w:] Wpływ zasobów niematerialnych na wartość firmy, Wydawnictwo UMCS, Lublin 2003.

Stewart T., The coins in the Knowledge Bank, Fortune [za:] Edvinsson L., Malone M. S., Kapitat intelektualny, Wydawnictwo Naukowe PWN, Warszawa 2001.

Storper M., The regional word. The territorial development in global economy, Guilford Press, 1997. 